\title{
GEOGRAPHICAL DISTRIBUTION OF TOXIC ELEMENTS IN NORTHEAST MARMARA SEA SEDIMENTS AND ANALYSIS OF TOXIC ELEMENT POLLUTION BY VARIOUS POLLUTION INDEX METHODS (ISTANBUL/TURKEY)
}

\author{
KAM, E. ${ }^{1}-$ YÜMÜN, Z. Ü. ${ }^{2 *}$

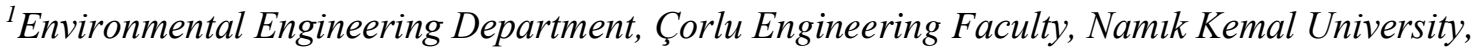 \\ 59860 Çorlu, Tekirdă̆, Turkey \\ (e-mail: erolkam@yildiz.edu.tr; ORCIDID:0000-0001-5850-5464) \\ ${ }^{2}$ Physics Department, Faculty of Arts and Sciences, Yildiz Technical University, Davutpaşa \\ Campus, 34220 Esenler/Istanbul, Turkey \\ *Corresponding author \\ e-mail: zyumun@nku.edu.tr; ORCID ID:0000-0003-0658-0416 \\ (Received $14^{\text {th }}$ Dec 2020; accepted $18^{\text {th }}$ Mar 2021)
}

\begin{abstract}
In this study, the geographic distribution of toxic element concentrations was determined in Northeast Marmara Sea (Istanbul/Turkey) sediments. In addition, the pollution degree of the environment was analyzed using various pollution index methods. Geochemical analysis of 28 elements were performed in sediment samples. The concentrations of several elements (especially Fe, Mn, Ti, Zn, and $\mathrm{Cr}$ ) were found to be very high in some locations. At sites, where heavy metal concentrations were high, foraminifera genera and species numbers and number of individuals were very low. The low number of foraminifera in the samples taken from some regions could be due to uncontrolled ship traffic and domestic and industrial discharges.
\end{abstract}

Keywords: geochemical analysis, marine sediments, elements, environmental index, pollution factors, eastern Marmara, Istanbul

\section{Introduction}

Historically, settlements were generally built near water bodies (seas, lakes, rivers) in order to meet the water needs of cleaning, nutrition, and agriculture, and to eliminate their waste. Pollution was not a serious issue due to low human population. However, in the last 30 years, as the population and the corresponding amount of waste has increased, the carrying capacity of the receiving aquatic environments has decreased (Algon et al., 2004; Yümün and Önce, 2017). Although many scientists have stated that the seas have been extremely polluted in the last 30 years, pollution has been ongoing since earlier times. The seas, which have been one of the major accumulation areas, are the largest water bodies affected by anthropogenic pollution. Apart from paper, plastic, and metal wastes, heavy metals, organic wastes, and inorganic wastes have also accumulated in the seabed sediment. Sediments provide necessary habitat for many freshwater, estuary, and marine organisms. Contaminated sediments endanger aquatic life and human health through direct toxicity as well as bioaccumulation in the food chain (Bakan et al., 1999; Knezovich and Harrison, 1987; Bampton, 1999). Contaminated sediments can cause lethal and sub-lethal effects in benthic zones and on other sediment-related organisms (Long et al., 1995). Therefore, it is important to measure the sediment quality when determining the quality of a water body. To determine the quality of sediment, it is necessary to perform toxic element analysis and 
to determine benthic health. These toxic elements are deposited in the sediment by precipitating towards the seabed without undergoing biodegradation. This accumulation causes morphological changes in the crust structures through limited movement or by passing to the sea floor. These organisms play a vital role as bioindicators in the determination of pollution in the seas. In recent years, many studies have used bioindicators and toxic element analysis to determine sediment quality (Yümün and Önce, 2017; Yümün, 2017, 2016; Kam and Önce, 2016; Meriç et al., 2012, 2009; Balkıs et al., 2007; Baştürk et al., 1988; Yümün and Kam, 2019; Yümün et al., 2019; Y1ldırım et al., 2010). In this study, heavy metal concentrations were determined in marine sediments of the Istanbul coast of Marmara Sea using core samples taken from 20 locations.

Some genera and species of Foraminifera cannot survive in dirty environments and a decrease is observed in their numerical abundance. In addition, elements such as $\mathrm{Fe}, \mathrm{S}$, $\mathrm{Mn}$ and $\mathrm{Mg}$ found in contaminated environments cause color changes in foraminiferal shells. Although the elements with toxic effects disrupt the living environment of the foraminifera, they may also cause the formation of anomalies in the foraminifera. For this reason, Foraminifers have been used as an indicator in terms of environmental pollution in many scientific studies (Yümün and Önce, 2017; Yümün, 2017; Meriç et al., 2012, 2009).

Therefore, the effects of pollution on the ecological system (study area) have been evaluated using foraminifera as bioindicators. Foraminiferal assemblages of the Marmara Sea sediments were identified in Istanbul. Foraminifer genera and species were examined to determine whether they originated from the Sea of Marmara.

In this study, toxic element concentrations and marine sediment pollution determination methods were applied to marine sediments of Northeast Marmara Sea. In addition, benthonic foraminifera assemblages of sediment samples taken in the Istanbul part of Marmara Sea were determined (Fig. 1).

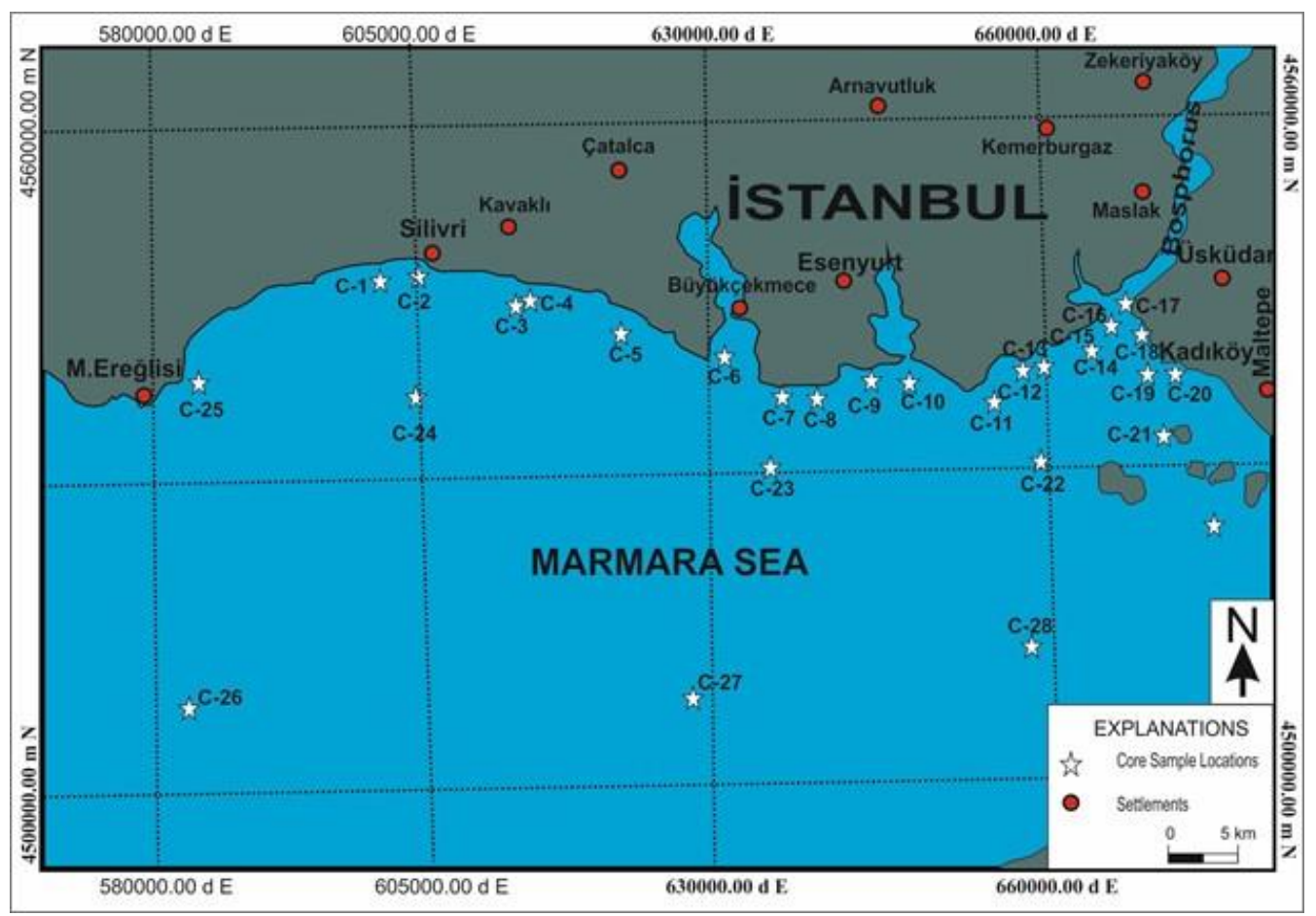

Figure 1. Location map of the study area 


\section{Sources of the pollutants}

Causes of marine environment pollution; Domestic wastes generated with population growth, pesticides and fertilizers used in agricultural activities, industrial wastes, maritime transport and the geological structure of the neighboring terrestrial area.

While the population of Istanbul 1971 was 3,126,400 (State Institute of Statistics (DIE)), the population in 2012 was $14,160,467$ and the current population (2021) is $15,634,257$. Here, it is seen that the population of Istanbul has increased approximately 5 times in 50 years. With this population growth, solid and liquid wastes and industrial wastes have also increased in parallel. In parallel with the population growth and the development of the industry, a serious increase is observed in maritime transport. The increase in the population has led to a decrease in agricultural land. If we evaluate the land use types between 1971 and 2012 in general, 32.7\% of the agricultural lands; Stateowned forest areas are observed to have decreased by $9.0 \%$ (Fig. 2). Between the two periods, residential areas are $409.8 \%$; quarry - sand - pasture - stony areas - nursery warehouse - facility - swamp - ENH - highway land group 269.8\%; water surfaces increased by $64.3 \%$. The most significant change in land use types occurred in agriculture and residential areas (Şahin, 2014).

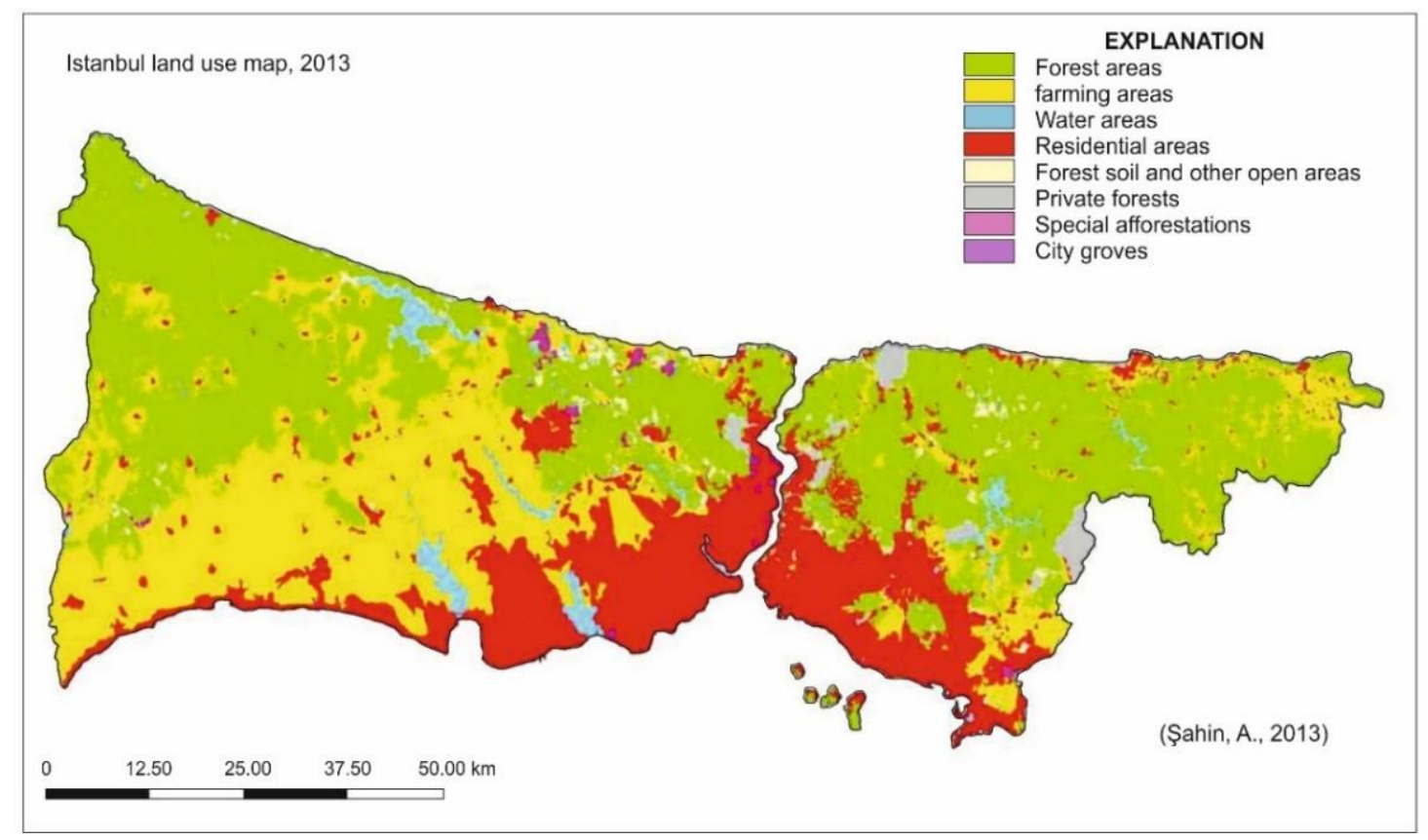

Figure 2. Istanbul land use map (Şahin, 2014)

Environmental pollution caused by sea transportation can be divided into two groups as "sea pollution" and "air pollution". Ships navigating international waters can cause unnatural displacement of different species. This displacement can negatively affect the ecosystem and thus affect human life negatively.

According to the data of IMO (International Maritime Organization), which is the top organization of the maritime sector at the international level, $8 \%$ of the wastes that cause pollution in the sea are from natural resources, $0.5 \%$ from offshore production, $11 \%$ from maritime transport and 30\% from the atmosphere, $40 \%$ from flood and land-based discharges, $10 \%$ from illegal discharge into the world seas (Küçük and Topçu, 2012). 
The most important causes of ship-related pollution in the seas: The discharge of bilge, dirty ballast or washing water to the sea, throwing garbage and similar domestic wastes into the sea, giving the oily and detergent water to the sea as a result of washing the decks, surface cleaning and painting of the outer surface discharge of the wastes arising from the transported loads into the sea, discharge of pollutant wastes on the deck with rainwater or ballast overflow water, leakage to the sea during fuel transfer, oil mixing with the cooling water of the ship engine and flowing into the sea with the cooling water, the leakage of the shaft sealing oil into the sea, the explosion of the hydraulic system on the decks the result is the flowing of the oil flowing into the sea and leaving the polluted water caused by life on the ship to the sea without treatment (Özdemir, 2012). Figure 3 shows the Turkey international Ro-Ro and roads on the map. Here, it is seen that the ship traffic is concentrated in Tekirdağ and Istanbul parts of the Marmara Sea. This density indicates that the Marmara Sea may cause the Tekirdağ and Istanbul parts to be contaminated (Kutluk, 2018).

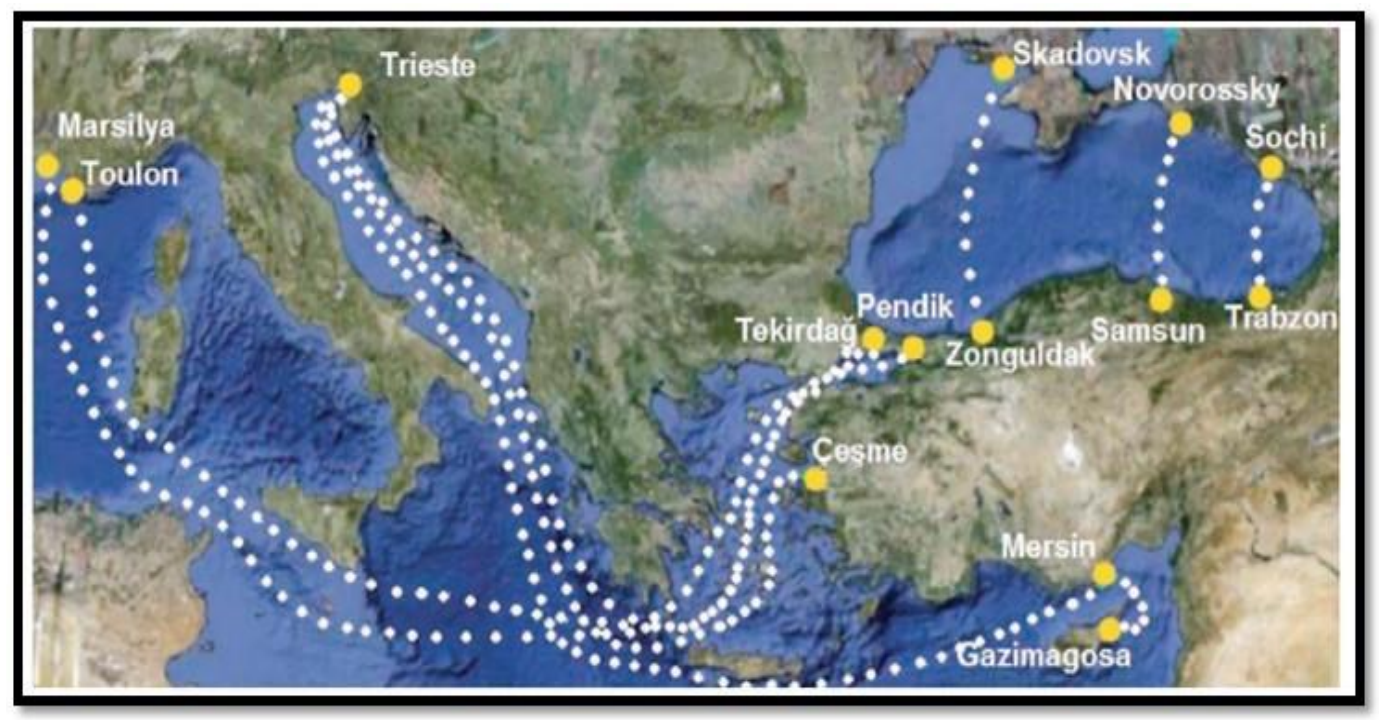

Figure 3. Turkish International Ro-Ro Lines (UP, 2011)

Lead is the most important heavy metal contaminant caused by transportation vehicles. Other metals that are polluted by transportation vehicles are $\mathrm{Cd}, \mathrm{Cu}, \mathrm{Cr}, \mathrm{Ni}$ and $\mathrm{Zn}$. These heavy metals are caused by the wear on the vehicle (Karaca, 1997).

\section{Materials and methods}

Core samples (seabed sediment) from 20 locations (Istanbul/Turkey) were used in the study. Core samples were obtained by a specially designed core-free method. Samples were taken from both clean areas and areas with high pollution potential, including domestic, industrial and port waste disposal sites. In this way, it is thought that the samples will represent the entire study area. Sample coordinates are given in Table 1 (Silivri-1, Silivri-2, Selimpaşa-1, Selimpaşa-2, Kumburgaz, Büyükçekmece, Gürpınar, Ambarlı, Avcılar, Küçükçekmece, Yeşilköy, Zeytinburnu, Yenikapı-1, Yenikapı-2, Kumkapi-1, Kumkapi-2, Bosphorus, Haydarpasa, Uskudar, and Kadikoy). Laboratory studies were carried out in two parts: Sieve analysis and Geochemical analysis. 
Table 1. Core samples and their coordinates taken from the shores of the West Marmara Sea in Istanbul

\begin{tabular}{c|c|c|c|c|c}
\hline $\begin{array}{c}\text { Core sample } \\
\text { No }\end{array}$ & $\begin{array}{c}\text { Core sample } \\
\text { location }\end{array}$ & Sample date & $\begin{array}{c}\text { Depth } \\
\text { (M) }\end{array}$ & \multicolumn{2}{|c}{ Geographic position } \\
\cline { 5 - 6 } C-1 & Silivri-1 & 10.06 .2019 & 25 & 4546298 & 0603555 \\
C-2 & Silivri-2 & 10.06 .2019 & 22 & 4546290 & 0603450 \\
C-3 & Selimpaşa-1 & 10.06 .2019 & 24 & 4543800 & 0614748 \\
C-4 & Selimpaşa-2 & 10.06 .2019 & 20 & 4543825 & 0614600 \\
C-5 & Kumburgaz & 10.06 .2019 & 38 & 4540935 & 0621468 \\
C-6 & Büyükçekmece & 10.06 .2019 & 20 & 4538709 & 0631551 \\
C-7 & Gürpınar & 10.06 .2019 & 23 & 4534925 & 0636700 \\
C-8 & Ambarlı & 10.06 .2019 & 22 & 4535178 & 0639489 \\
C-9 & Avcılar & 10.06 .2019 & 21 & 4536219 & 0644673 \\
C-10 & Küçükçekmece & 10.06 .2019 & 28 & 4536629 & 0648076 \\
C-11 & Yeşilköy & 10.06 .2019 & 17 & 4534694 & 0656542 \\
C-12 & Zeytinburnu & 10.06 .2019 & 18 & 4536482 & 0659244 \\
C-13 & Yenikap1-1 & 10.06 .2019 & 21 & 4539708 & 0664909 \\
C-14 & Yenikap1-2 & 11.06 .2019 & 30 & 4539598 & 0665458 \\
C-15 & Kumkap1-1 & 11.06 .2019 & 32 & 4539722 & 0666198 \\
C-16 & Kumkap1-2 & 11.06 .2019 & 18 & 4540490 & 0666165 \\
C-17 & Boğaziçi & 11.06 .2019 & 51 & 4541007 & 0667563 \\
C-18 & Haydarpaşa & 11.06 .2019 & 18 & 4540766 & 0668134 \\
C-19 & Üsküdar & 11.06 .2019 & 16 & 4538517 & 0668634 \\
C-20 & Kadı̈öy & 11.06 .2019 & 16 & 4535730 & 0669586 \\
C-21 & Kınalı Island & 11.06 .2019 & 35 & 4531005.94 & 671256.44 \\
C-22 & C-I.22 & 11.06 .2019 & 65 & 4528966.90 & 660167.75 \\
C-23 & C-I.23 & 11.06 .2019 & 75 & 4528463.42 & 635770.20 \\
C-24 & C-I.24 & 11.06 .2019 & 85 & 4534723.57 & 603312.94 \\
C-25 & M. Ereğlisi & 11.06 .2019 & 32 & 4537387.00 & 582550.00 \\
\hline & & & & & \\
& & & &
\end{tabular}

\section{Sieve analysis}

Core samples obtained from the study area were divided into $10 \mathrm{~cm}$ sections. From these sections, $15 \mathrm{~g}$ samples were placed in beakers. In order to obtain foraminifera, the sediment samples were kept in $10 \% \mathrm{H}_{2} \mathrm{O}_{2}$ for $24 \mathrm{~h}$. Following this procedure, the sediment samples were washed with water in a 63-micron sieve. The washed samples were dried in a $50{ }^{\circ} \mathrm{C}$ oven and examined under a binocular microscope to differentiate the foraminiferal shells.

\section{Geochemical analysis}

Geochemical analysis for the elements (Fe, $\mathrm{Zn}, \mathrm{Al}, \mathrm{Mn}, \mathrm{As}, \mathrm{B}, \mathrm{Co}, \mathrm{Cr}, \mathrm{Cu}, \mathrm{Ni}, \mathrm{Sb}$, $\mathrm{Na}, \mathrm{Mg}, \mathrm{K}, \mathrm{Ca}, \mathrm{P}, \mathrm{Pb}, \mathrm{Hg}, \mathrm{Cd}, \mathrm{Ag}, \mathrm{Bi}, \mathrm{Cd}, \mathrm{Mo}, \mathrm{Pb}, \mathrm{Pt}, \mathrm{Sn}, \mathrm{Se}$, and $\mathrm{Hg}$ ) was carried out using the SPECTROBLUE model Induced Matched Plasma-Optic Emission Spectrometer (ICP-OES) device. Samples to be analyzed with ICP-OES devices, firstly being dissolved by the suitable method (King water method, triple acid method, melting method, TS ISO 14869-1, TS ISO 14869-2 etc.). Then samples which dissolved have been analyzed with TSE, 2004/a-b method. 
Approximately $20 \mathrm{~g}$ samples were taken from the elementary levels for wet sieve analysis. After drying, the sediment samples were beaten with the help of mortar and the grains were separated. From these, $0.5 \mathrm{~g}$ samples were extracted and $12 \mathrm{ml}$ of $\mathrm{HNO}_{3}$ and $4 \mathrm{ml}$ of $\mathrm{HCl}$ were added to the samples, which were then placed in incineration tubes and burned for $1 \mathrm{~h}$ at $98{ }^{\circ} \mathrm{C}$ and $1.5 \mathrm{~h}$ at $200{ }^{\circ} \mathrm{C}$. After the cooling tubes opened in the fume hood, they were filled with $50 \mathrm{ml}$ of ultra-pure water and filtered using filter papers. Prepared samples were put into the measurement unit of ICP-OES and readings were recorded (Yümün and Önce, 2017; Morillo et al., 2002; Galuszka et al., 2014). Sedimentary samples were taken by the Gravity Core method and the sample sizes are 50-100 $\mathrm{cm}$. In order to evaluate the samples homogeneously, analyzes were made by taking them at $10 \mathrm{~cm}$ intervals. The average value of the geochemical analysis results of all samples taken from each core sample was taken and used in evaluations.

\section{Sediment pollution analysis methods}

Sediment Contamination Assessment Methods were applied to the geochemical analysis results of sediment samples taken in the study area. These methods are; Enrichment Factor (EF) (Buat et al., 1979; Mason and Moore, 1982). Contamination factor (Cfi) (Hakanson, 1980), Pollution Load Index (PLI) (Tomlinson et al., 1980) and Pollution Index (PI) (Yümün, 2017). The results obtained with the methods were interpreted by correlation.

\section{Results and discussion}

\section{Geochemical analysis}

Geochemical analysis of sediment samples taken from seabed was performed by ICP-OES method. Geochemical analysis results show that heavy metal concentrations are very high in most of the locations (especially Küçükçekmece, Ambarlı, Büyükçekmece) (Tables 2 and 3). Geochemical analysis results show very high differences between the elements in ppm. Those with concentration values in the range of 0-1000 ppm were considered as First Group Elements (Table 2) and those with values greater than 1000 ppm as Second Group Elements (Table 3).

From the elements defined as the first group of elements, there are locations where $\mathrm{Mn}, \mathrm{P}, \mathrm{Cr}, \mathrm{Ti}, \mathrm{Zn}$ and $\mathrm{Cu}$ concentrations are higher than average values. Of the elements evaluated as the second group of elements, $\mathrm{Ca}$ and $\mathrm{K}$ are high in some locations, while other elements are close to average values. Sediment Pollution Analysis was applied to determine the total pollution status and the polluting elements for each location.

\section{Sediment pollution analysis}

\section{Enrichment factor $(E F)$}

Enrichment Factor is a method of determining the rate of heavy metal pollution from anthropogenic origin in soil or wet environment sediments. It is very common to calculate the enrichment factor in order to determine the anthropogenic effects in sediments (Galuszka et al., 2014). The purpose of this method is the ratio of contamination to natural concentrations by a normalization factor (Daskalakis and O’Connor, 1995; Feng et al., 2004). 
Table 2. First group element concentrations and pollution index of Marmara Sea in Istanbul

\begin{tabular}{|c|c|c|c|c|c|c|c|c|c|c|}
\hline Sample No & $\mathbf{Z n}$ & Mn & As & B & Co & $\mathrm{Cr}$ & $\mathbf{C u}$ & $\mathbf{N i}$ & $\mathbf{T i}$ & $\mathbf{P}$ \\
\hline Silivri-1 & 63.86 & 352.00 & 4.04 & 34.25 & 13.63 & 74.11 & 24.39 & 104.05 & 203.90 & 390.10 \\
\hline Silivri-2 & 63.49 & 358.2 & 2.61 & 38.73 & 13.94 & 82.05 & 24.30 & 105.19 & 277.86 & 396.13 \\
\hline Selimpaşa-1 & 54.26 & 310.30 & 3.04 & 63.98 & 10.97 & 69.63 & 21.47 & 76.71 & 288.80 & 331.80 \\
\hline Selimpaşa-2 & 62.28 & 358.63 & 4.14 & 60.68 & 15.09 & 81.58 & 30.76 & 110.4 & 298.89 & 363.73 \\
\hline Kumburgaz & 63.21 & 374.32 & 2.25 & 57.00 & 12.72 & 74.25 & 27.32 & 82.17 & 259.06 & 261.75 \\
\hline Büyükçekmece & 69.42 & 460.88 & 10.03 & 53.81 & 14.69 & 80.22 & 38.40 & 96.67 & 248.63 & 273.75 \\
\hline Gürpınar & 51.10 & 246.50 & 2.39 & 27.96 & 8.51 & 43.58 & 26.79 & 42.50 & 167.96 & 261.12 \\
\hline Ambarl1 & 72.40 & 252.03 & 3.01 & 32.97 & 7.64 & 49.87 & 51.81 & 45.57 & 138.77 & 269.25 \\
\hline Avcilar & 76.03 & 214.60 & 2.82 & 24.17 & 7.61 & 42.13 & 39.06 & 38.42 & 121.28 & 302.22 \\
\hline Küçükçekmece & 87.00 & 259.00 & 2.28 & 28.65 & 7.71 & 44.43 & 48.53 & 36.87 & 116.69 & 580.70 \\
\hline Yeşilköy & 62.23 & 170.26 & 3.46 & 31.23 & 4.89 & 86.24 & 40.17 & 25.64 & 142.87 & 284.43 \\
\hline Zeytinburnu & 219.8 & 288.6 & 4.75 & 55.66 & 6.84 & 197.64 & 135.4 & 42.03 & 138.45 & 545.76 \\
\hline Yenikapı-1 & 83.15 & 218.2 & 7.47 & 48.64 & 6.56 & 133.15 & 62.01 & 30.82 & 126.02 & 485.35 \\
\hline Yenikapı-2 & 65.43 & 180.25 & 4.78 & 30.62 & 5.31 & 87.00 & 40.26 & 23.75 & 114.94 & 341.4 \\
\hline Kumkapı -1 & 106.72 & 235.6 & 7.87 & 31.18 & 6.41 & 103.50 & 88.54 & 29.51 & 117.31 & 931.95 \\
\hline Kumkapı -2 & 160.47 & 225.35 & 8.62 & 45.62 & 6.44 & 174.12 & 126.44 & 33.45 & 152.17 & 850.9 \\
\hline Boğaziçi & 66.37 & 201.60 & 3.40 & 20.52 & 5.79 & 36.72 & 51.50 & 23.59 & 90.63 & 385.10 \\
\hline Haydarpaşa & 52.99 & 223.36 & 2.57 & 16.93 & 6.51 & 35.17 & 26.31 & 24.93 & 94.96 & 321.5 \\
\hline Üsküdar & 88.47 & 335.73 & 3.80 & 28.98 & 10.17 & 58.92 & 58.42 & 45.41 & 152.75 & 675.13 \\
\hline Kadıköy & 79.77 & 292.73 & 3.50 & 27.75 & 8.33 & 49.69 & 55.00 & 35.15 & 156.41 & 341.96 \\
\hline Kınalı Island & 28.00 & 125.00 & 1.55 & 11.01 & 5.20 & 45.00 & 28.50 & 35.00 & 125.01 & 201.10 \\
\hline C-I.22 & 25.05 & 135.02 & 2.02 & 21.06 & 7.03 & 65.21 & 23.32 & 45.01 & 123.03 & 213.02 \\
\hline C-I.23 & 34.02 & 134.01 & 2.50 & 22.11 & 8.70 & 56.05 & 22.25 & 32.05 & 89.00 & 211.01 \\
\hline C-I.24 & 45.03 & 154.05 & 3.20 & 23.15 & 6.50 & 55.00 & 26.10 & 34.05 & 98.05 & 223.05 \\
\hline M. Ereğlisi & 42.30 & 163.20 & 23.57 & 67.24 & 38.69 & 46.10 & 9.35 & 106.4 & 1.29 & 285.20 \\
\hline $\begin{array}{l}\text { Main value of } \\
\text { Istanbul region in } \\
\text { Marmara Sea }\end{array}$ & 74.2 & 254.40 & 4.01 & 34.85 & 8.63 & $\underline{76.04}$ & $\underline{46.52}$ & 49.95 & 160.14 & 393.42 \\
\hline $\begin{array}{c}\text { The main values of } \\
\text { Marmara Sea }\end{array}$ & 88.54 & 388.9 & 18.05 & 61.7 & 30.36 & 62.17 & 30.3 & 78.63 & 170.4 & 741.5 \\
\hline
\end{tabular}

In calculating this index, background values of various normalization elements determined by different methods are used. By taking iron $(\mathrm{Fe})$ as the reference element, the effect of large differences in grain size, carbonate dilution and mineral content is eliminated. Bekground elements ( $\mathrm{Cr}, \mathrm{Mn}, \mathrm{Ni}, \mathrm{Cu}, \mathrm{Zn}, \mathrm{As}, \mathrm{Ti}, \mathrm{Al}, \mathrm{Ca}$ and $\mathrm{Fe}$ ) are used to reduce metal variations caused by grain size and mineral structure, to detect metal anomalies and to ensure geochemical normalization of metals. Elements ( $\mathrm{Al}, \mathrm{Fe}$, Zirkon, Li), which are not geochemically active and can be found easily in fine-grained materials, are used as normalization factor (Rodríguez-Barroso et al., 2009]. Among these elements, $\mathrm{Al}$ is the dominant element in the earth's crust and $\mathrm{Fe}$ is the dominant element in the structure of clay minerals (Morillo et al., 2002; Adamo, 2005; Valdes et al., 2005). In many studies, iron is used as a normalization element since it is thought that the distribution of iron is not related to other heavy metals in the enrichment factor calculations (Niencheski, 1994). Since this study analyzed the element contents of sea sediments (sandy, silty clay and silty clay), Fe was used as the normalization element in the enrichment factor calculations. In the absence of anthropogenic inputs, the average shale metal concentrations are taken into consideration in the evaluation of the metal concentrations of the marine sediments (Algan et al., 2004; Pekey, 2004; Taylor and McLennan, 1995; Aksu et al., 1997; Sarı and Çağatay, 2001; Sarı, 2004). Because shales in marine environments best represent the top level of the earth's crust. For this reason, the shale concentrations (Mason and Moore, 1982; Turekian and Wedepohl, 1961; Krauskopf, 1985) given in Table 4 were used in this study. In this study, 
enrichment factor $(\mathrm{EF})$ of metals $(\mathrm{Zn}, \mathrm{As}, \mathrm{Co}, \mathrm{Cu}, \mathrm{Ni}, \mathrm{Pb}$ and $\mathrm{Mn}$ ) was calculated using heavy metal analysis results. The Enrichment Factor is calculated (Table 5) by the Equation 1 below, defined by Buat et al. (1979):

$$
\mathrm{EF}=(\mathrm{Cn} / \mathrm{Cref}) /(\mathrm{Bn} / \mathrm{Bref})
$$

In the formula, EF: Enrichment factor, Cn: Metal value measured in the study, Cref: Value of the reference element (Fe) measured in the study, Bn: Background (shale) value of the measured element, Bref: Background (shale) value of the reference element. The calculated $\mathrm{EF}$ value result close to $1(\mathrm{EF}<1)$ indicates the shell origin, while $1<\mathrm{EF}<3$ shows little enrichment. The fact that it is between $3<\mathrm{EF}<5$ is arguably accepted that it is of shell origin (very enrichment) and if EF $>5$ is definitely not of shell origin (Galuszka et al., 2014; Halstead et al., 2000).

Table 3. Second group element concentrations and pollution index of Marmara Sea in Istanbul

\begin{tabular}{|c|c|c|c|c|c|c|c|}
\hline Sample No & $\mathbf{S}$ & Al & $\mathbf{F e}$ & $\mathrm{Na}$ & $\mathrm{Mg}$ & $\mathbf{K}$ & $\mathbf{C a}$ \\
\hline Silivri-1 & 3621.1 & 9610.6 & 24425.20 & 10851.10 & 13685.30 & 4267.00 & 92360.80 \\
\hline Silivri-2 & 3641.86 & 13606.3 & 25687.83 & 10496.3 & 14196.13 & 5055.36 & 77036.43 \\
\hline Selimpaşa-1 & 4852.1 & 14509.5 & 23896.90 & 16612.50 & 15718.70 & 7550.30 & 136555.00 \\
\hline Selimpaşa-2 & 4307.63 & 15762.6 & 28407.26 & 13868.2 & 15829.93 & 7890.56 & 143896.33 \\
\hline Kumburgaz & 3536.72 & 10112.40 & 26039.22 & 15505.70 & 9195.28 & 9544.93 & 4218.64 \\
\hline Büyükçekmece & 5372.88 & 11055.57 & 29073.15 & 15002.20 & 9162.75 & 9702.57 & 3060.70 \\
\hline Gürpınar & 3102.73 & 7703.62 & 17021.82 & 10103.10 & 6207.23 & 5562.85 & 69675.42 \\
\hline Ambarl & 2835.43 & 6982.60 & 15735.95 & 13266.90 & 7055.73 & 5850.90 & 85185.90 \\
\hline Avcılar & 2674.47 & 6438.17 & 13430.07 & 9760.65 & 5732.68 & 4587.20 & 63675.02 \\
\hline Küçükçekmece & 3044.38 & 7044.40 & 14044.15 & 13100.13 & 6057.83 & 4773.10 & 32710.13 \\
\hline Yeşilköy & 3509.16 & 8537.46 & 12065.13 & 9757.1 & 7367.7 & 3910.36 & 133015.33 \\
\hline Zeytinburnu & 6483 & 12746.06 & 19752.96 & 14073.13 & 16002.73 & 6593.83 & 19230.70 \\
\hline Yenikapı-1 (Iç) & 6293.3 & 11518.35 & 14065.5 & 11634.35 & 10549.95 & 5271.2 & 183733 \\
\hline Yenikapı-2 (Dış) & 4254.35 & 8836.15 & 17746.9 & 7813.8 & 7283.2 & 3532.35 & 116516.5 \\
\hline Kumkapı -1 & 4325.9 & 8673.7 & 16428.5 & 9154.9 & 7358.75 & 3512.3 & 113774.85 \\
\hline Kumkapı -2 & 7726 & 9827.3 & 18727.55 & 11370.45 & 9941.3 & 4918.4 & 125067.35 \\
\hline Boğaziçi & 1674.3 & 7075.9 & 13969.60 & 5865.20 & 6599.70 & 2207.20 & 112445.00 \\
\hline Haydarpaşa & 1581.43 & 7354.76 & 14567.36 & 6232.46 & 2098.9 & 90617.03 & 6232.46 \\
\hline Üsküdar & 2694.3 & 12293.8 & 22336.7 & 7614.56 & 7511.63 & 3739.16 & 43245 \\
\hline Kadıköy & 2527.86 & 11572.26 & 19843.67 & 7995.03 & 6863.46 & 3752.60 & .52046 .2 \\
\hline Kınalı Island & 856.4 & 856.00 & 11025.12 & 1520.10 & 2050.05 & 1250.15 & 2850.10 \\
\hline C-I.22 & 768.00 & 900.05 & 11567.10 & 1566.15 & 2312.10 & 1125.10 & 2675.15 \\
\hline C-I.23 & 769.05 & 875.10 & 12546.21 & 1377.02 & 3451.02 & 2311.20 & 2543.20 \\
\hline C-I.24 & 789.10 & 1056.10 & 13456.20 & 1432.05 & 3532.05 & 245421 & 2345.00 \\
\hline M. Ereğlisi & 776.03 & 17768.2 & 20936.90 & 6046.80 & 4800.40 & 3290.80 & 80924.20 \\
\hline $\begin{array}{c}\text { Main value of Istanbul } \\
\text { region in Marmara } \\
\text { Sea }\end{array}$ & 3385.05 & 8539.52 & 18160.81 & 9415.53 & $\underline{8156.83}$ & $\underline{\mathbf{8 3 3 2 . 4 7}}$ & 67670.57 \\
\hline $\begin{array}{c}\text { The main values of } \\
\text { Marmara Sea }\end{array}$ & 3775.62 & 15291.00 & 25210.92 & 9741.96 & 7536.66 & 7214.30 & 71985.69 \\
\hline
\end{tabular}


Table 4. Heavy metal concentrations of some geological reference rocks (Turekian and Wedepohl, 1961; Krauskopf, 1985)

\begin{tabular}{c|c|c|c|c|c|c|c|c}
\hline Elements & Unit & Earth crust & Shale & Sandstone & Limestone & Ultrabasics & Basalt & Deep sea clays \\
\hline $\mathrm{Fe}$ & $\%$ & 5.00 & 4.70 & 0.98 & 0.38 & 9.40 & 8.60 & 6.50 \\
$\mathrm{Zr}$ & $\mathrm{ppm}$ & 165.00 & 180.00 & 19.00 & - & 45.00 & 140.00 & 150.00 \\
$\mathrm{Cr}$ & $\mathrm{ppm}$ & 100.00 & 90.00 & 35.00 & 11.00 & 1600.00 & 170.00 & 90.00 \\
$\mathrm{Mn}$ & $\mathrm{ppm}$ & 950.00 & 850.00 & 50.00 & 1100.00 & 1620.00 & 1500.00 & 6700.00 \\
$\mathrm{Ni}$ & $\mathrm{ppm}$ & 75.00 & 70.00 & 2.00 & 20.00 & 2000.00 & 130.00 & 225.00 \\
$\mathrm{Cu}$ & $\mathrm{ppm}$ & 55.00 & 45.00 & 5.00 & 4.00 & 10.00 & 87.00 & 250.00 \\
$\mathrm{Zn}$ & $\mathrm{ppm}$ & 70.00 & 95.00 & 16.00 & 20.00 & 50.00 & 105.00 & 165.00 \\
$\mathrm{Cd}$ & $\mathrm{ppm}$ & 0.10 & 0.30 & - & - & - & 0.20 & 0.40 \\
$\mathrm{~Pb}$ & $\mathrm{ppm}$ & 13.00 & 20.00 & 7.00 & 9.00 & 1.00 & 6.00 & 80.00 \\
$\mathrm{As}$ & $\mathrm{ppm}$ & 1.80 & 13.00 & 1.00 & 1.00 & 1.00 & 2.00 & 13.00 \\
$\mathrm{~V}$ & $\mathrm{ppm}$ & 135.00 & 130.00 & 20.00 & 20.00 & 40.00 & 250.00 & 120.00 \\
$\mathrm{Sb}$ & $\mathrm{ppm}$ & 0.20 & 1.50 & - & 0.20 & 0.10 & 0.20 & 1.00 \\
\hline
\end{tabular}

While the enrichment of $\mathrm{Cu}$ and $\mathrm{Zn}$ is seen in many locations, the $\mathrm{Ni}$ enrichment in Silivri and Gürpınar is remarkable. In the analysis, Ni enrichment was determined to be very rich in Silivri (3.2) and Gürpınar (4.1) samples. Copper $(\mathrm{Cu})$ enrichment is very high in Selimpaşa-2 (3.2), Kumburgaz (3.1), Büyükçekmece (3.1), Yenikap1-1 (4.9), Boğaziçi (4.1), Ambarlı (3.7), Küçükçekmece (3.5). In Kumkap1-1 (6.0), Kumkap1-2 (7.5), Yeşilköy (7.9), Gürpınar (5.3) and Zeytinburnu (7.6), there is excessive enrichment. Zinc ( $\mathrm{Zn})$ enrichment is very rich in Yenikap1-1 (3.1), Kumkap1-1 (3.4), Kumkap1-2 (4.5) and Küçükçekmece (3.3); Excessive enrichment was observed in Zeytinburnu (5.9). Too much enrichment definitely shows that the sources of pollution are not natural. In all other locations, the enrichment factor of all elements was found to be less than 3 , and these values show that there is little or no enrichment.

\section{Contamination factor (Cfi)}

Contamination factor is a method that is used frequently in studies investigating the origin of heavy metal concentrations in sediments and defines the current situation. Contamination factor calculations for the study area are given in Table 6 and pollution factor classification is given in Table 7. The Contamination Factor was calculated by the correlation (2) defined by Hakanson (1980).

$$
C f i=C i / C n i
$$

In the formula, $\mathrm{Ci}$ is the metal value measured in sediment and $\mathrm{Cni}$ is the preindustry reference value of the metal. Nickel contamination (CfNi); Silivri-1 (1.5), Silivri-2 (1.5), Selimpaşa-1 (1.1), Selimpaşa-2 (1.6), Kumburgaz (1.2), Büyükçekmece (1.3), Gürpınar (1.4). Copper contamination (CfCu); Selimpaşa-2 (1.8), Kumburgaz (1.7), Büyükçekmece (1.8), Gürpınar (1.8), Ambarlı (1.15) and Kumkapı (1.9) are also seen. Zinc (CfZn) contamination value is seen at medium level in Kumkap1-1 (1.12). Moderate and little contamination is observed for all elements in all other locations. 
Table 5. Enrichment factor values calculated in the study area

\begin{tabular}{|c|c|c|c|c|}
\hline \multicolumn{2}{|c|}{ Silivri -1 } & \multirow{2}{*}{$\begin{array}{c}\text { Silivri-2 } \\
\text { Enrichment value }\end{array}$} & \multirow{2}{*}{\begin{tabular}{|c|} 
Selimpaşa-1 \\
enrichment value
\end{tabular}} & \multirow{2}{*}{\begin{tabular}{|c|} 
Selimpaşa-2 \\
Enrichment value
\end{tabular}} \\
\hline Toxic elements & Enrichment value & & & \\
\hline $\mathrm{EF}_{\mathrm{Mn}}$ & 0.85 & 0.80 & 0.80 & 0.75 \\
\hline $\mathrm{EF}_{\mathrm{Co}}$ & 1.50 & 1.40 & 1.20 & 1.40 \\
\hline $\mathrm{EF}_{\mathrm{Ni}}$ & $\underline{3.10}$ & $\underline{2.90}$ & $\underline{2.30}$ & $\underline{2.80}$ \\
\hline $\mathrm{EF}_{\mathrm{Cu}}$ & 1.10 & 1.10 & 1.00 & 3.20 \\
\hline $\mathrm{EF}_{\mathrm{Zn}}$ & 1.40 & 1.30 & 1.20 & 1.20 \\
\hline \multirow[t]{2}{*}{$\mathrm{EF}_{\mathrm{As}}$} & 0.60 & 0.40 & 0.50 & 0.56 \\
\hline & Kumburgaz & Büyükçekmece & Yenikapı-1 & Yenikapı-2 \\
\hline Toxic elements & Enrichment value & Enrichment value & Enrichment value & Enrichment value \\
\hline $\mathrm{EF}_{\mathrm{Mn}}$ & 0.80 & 1.20 & 0.90 & 0.60 \\
\hline $\mathrm{EF}_{\mathrm{Co}}$ & 1.20 & 1.30 & 1.20 & 0.80 \\
\hline $\mathrm{EF}_{\mathrm{Ni}}$ & 2.30 & 2.40 & 1.60 & 0.90 \\
\hline $\mathrm{EF}_{\mathrm{Cu}}$ & 3.10 & 3.10 & 4.90 & 2.50 \\
\hline $\mathrm{EF}_{\mathrm{Zn}}$ & 1.30 & 1.30 & 3.10 & 1.90 \\
\hline \multirow[t]{2}{*}{$\mathrm{EF}_{\mathrm{As}}$} & 0.30 & 1.30 & 2.10 & 1.10 \\
\hline & Kumkapı-1 & Kumkapı-2 & Boğaziçi & Üsküdar \\
\hline Toxic elements & Enrichment value & Enrichment value & Enrichment value & Enrichment value \\
\hline $\mathrm{EF}_{\mathrm{Mn}}$ & 0.80 & 0.70 & 0.80 & 0.60 \\
\hline $\mathrm{EF}_{\mathrm{Co}}$ & 1.10 & 0.90 & 1.10 & 1.20 \\
\hline $\mathrm{EF}_{\mathrm{Ni}}$ & 1.30 & 1.30 & 1.20 & 1.50 \\
\hline $\mathrm{EF}_{\mathrm{Cu}}$ & $\underline{6.00}$ & $\underline{7.50}$ & 4.10 & 2.90 \\
\hline $\mathrm{EF}_{\mathrm{Zn}}$ & $\underline{3.40}$ & $\underline{4.50}$ & 2.50 & 2.10 \\
\hline \multirow[t]{2}{*}{$\mathrm{EF}_{\mathrm{As}}$} & 1.80 & 1.80 & 0.90 & 0.70 \\
\hline & Gürpınar & Ambarlı & Avcılar & Küçükçekmece \\
\hline Toxic elements & Enrichment value & Enrichment value & Enrichment value & Enrichment value \\
\hline $\mathrm{EF}_{\mathrm{Mn}}$ & 0.80 & 0.90 & 0.90 & 1.10 \\
\hline $\mathrm{EF}_{\mathrm{Co}}$ & 2.30 & 1.30 & 1.50 & 1.40 \\
\hline $\mathrm{EF}_{\mathrm{Ni}}$ & 4.10 & 2.10 & 2.10 & 1.90 \\
\hline $\mathrm{EF}_{\mathrm{Cu}}$ & 5.30 & 3.70 & 3.50 & 3.50 \\
\hline $\mathrm{EF}_{\mathrm{Zn}}$ & 1.50 & 2.40 & 2.90 & 4.38 \\
\hline \multirow[t]{2}{*}{$\mathrm{EF}_{\mathrm{As}}$} & 0.50 & 0.70 & 0.80 & 0.60 \\
\hline & Yeşilköy & Zeytinburnu & Haydarpaşa & Kadıköy \\
\hline Toxic elements & Enrichment value & Enrichment value & Enrichment value & Enrichment value \\
\hline $\mathrm{EF}_{\mathrm{Mn}}$ & 0.80 & 0.90 & 0.80 & 0.90 \\
\hline $\mathrm{EF}_{\mathrm{Co}}$ & 1.10 & 0.90 & 1.20 & 1.10 \\
\hline $\mathrm{EF}_{\mathrm{Ni}}$ & 1.50 & 1.50 & 1.20 & 1.20 \\
\hline $\mathrm{EF}_{\mathrm{Cu}}$ & 7.90 & 7.60 & 2.00 & 3.10 \\
\hline $\mathrm{EF}_{\mathrm{Zn}}$ & 2.70 & 5.90 & 1.90 & 2.10 \\
\hline $\mathrm{EF}_{\mathrm{As}}$ & 1.10 & 0.90 & 0.70 & 0.60 \\
\hline
\end{tabular}


Table 6. Contamination factor values calculated for the study area

\begin{tabular}{c|c|c|c|c|c|c|c}
\hline Sample locations & $\mathbf{C}_{\mathbf{f}} \mathbf{M n}$ & $\mathbf{C}_{\mathbf{f}} \mathbf{F e}$ & $\mathbf{\mathbf { C } _ { \mathbf { f } } \mathbf { N i }}$ & $\mathbf{\mathbf { C } _ { \mathbf { f } } \mathbf { C u }}$ & $\mathbf{C}_{\mathbf{f}} \mathbf{Z n}$ & $\mathbf{C}_{\mathbf{f}} \mathbf{C o}$ & $\mathbf{C}_{\mathbf{f}} \mathbf{A s}$ \\
\hline Silivri-1 & 0.40 & 0.51 & $\underline{\mathbf{1 . 5 0}}$ & 0.50 & 0.70 & 0.70 & 0.30 \\
Silivri-2 & 0.40 & 0.55 & $\underline{\mathbf{1 . 5 0}}$ & 0.54 & 0.70 & 0.73 & 0.20 \\
Selimpaşa-1 & 0.40 & 0.50 & $\underline{\mathbf{1 . 1 0}}$ & 0.50 & 0.60 & 0.60 & 0.20 \\
Selimpaşa-2 & 0.42 & 0.60 & $\underline{\mathbf{1 . 6 0}}$ & $\underline{\mathbf{1 . 8 0}}$ & 0.70 & 0.80 & 0.30 \\
Kumburgaz & 0.40 & 0.55 & $\underline{\mathbf{1 . 2 0}}$ & $\underline{\mathbf{1 . 7 0}}$ & 0.70 & 0.70 & 0.20 \\
Büyükçekmece & 0.50 & 0.60 & $\underline{\mathbf{1 . 3 0}}$ & $\underline{\mathbf{1 . 8 0}}$ & 0.70 & 0.80 & 0.80 \\
Gürpınar & 0.30 & 0.36 & $\underline{\mathbf{1 . 4 0}}$ & $\underline{\mathbf{1 . 8 0}}$ & 0.53 & 0.77 & 0.18 \\
Ambarlı & 0.29 & 0.33 & 0.65 & $\underline{\mathbf{1 . 1 5}}$ & 0.76 & 0.40 & 0.23 \\
Avc1lar & 0.25 & 0.28 & 0.55 & 0.93 & 0.80 & 0.40 & 0.21 \\
Küçükçekmece & 0.30 & 0.29 & 0.53 & 0.98 & 0.95 & 0.40 & 0.17 \\
Yeşilköy & 0.20 & 0.25 & 0.36 & 1.91 & 0.65 & 0.25 & 0.26 \\
Zeytinburnu & 0.30 & 0.40 & 0.60 & $\underline{\mathbf{3 . 0 0}}$ & $\underline{\mathbf{2 . 3 0}}$ & 0.36 & 0.36 \\
Yenikapi-1 & 0.21 & 0.37 & 0.34 & 0.89 & 0.69 & 0.27 & 0.36 \\
Yenikapi-2 & 0.20 & 0.35 & 0.32 & $\mathbf{0 . 7 3}$ & 0.93 & 0.21 & 0.32 \\
Kumkapi-1 & 0.27 & 0.35 & 0.42 & $\underline{\mathbf{1 . 9 0}}$ & $\mathbf{1 . 1 2}$ & 0.33 & 0.60 \\
Kumkap1-2 & 0.26 & 0.39 & 0.48 & $\underline{\mathbf{2 . 8 0}}$ & $\underline{\mathbf{1 . 6 0}}$ & 0.33 & 0.70 \\
Boğaziçi & 0.23 & 0.29 & 0.33 & $\underline{\mathbf{1 . 2 0}}$ & 0.69 & 0.30 & 0.26 \\
Haydarpaşa & 0.24 & 0.30 & 0.35 & $\mathbf{0 . 5 8}$ & 0.55 & 0.34 & 0.19 \\
Üsküdar & 0.26 & 0.47 & 0.65 & $\underline{\mathbf{1 . 3 0}}$ & 0.93 & 0.53 & 0.29 \\
Kadıköy & 0.30 & 0.40 & 0.50 & $\underline{\mathbf{1 . 2 0}}$ & 0.83 & 0.43 & 0.27 \\
\hline
\end{tabular}

Table 7. Pollution factor (Cf) classification Hakanson (1982)

\begin{tabular}{c|c}
\hline $\mathbf{C}_{\mathrm{f}}$ & Sediment quality \\
\hline $\mathrm{C}_{\mathrm{f}}<1$ & Little contamination \\
$1<\mathrm{C}_{\mathrm{f}}<3$ & Midle contamination \\
$3<\mathrm{C}_{\mathrm{f}}<6$ & Significant contamination \\
$\mathrm{C}_{\mathrm{f}}>6$ & Very high contamination \\
\hline
\end{tabular}

\section{Pollution load index (PLI)}

Pollution Load Index is a method that evaluates the pollution level of heavy metals. PLI is defined by the $\mathrm{n}$ root of the product of the ratio of the concentration of each element measured to the background values (Tomlinson, 1980).

$$
\begin{gathered}
\text { PLI }=\left(\mathrm{C}_{\mathrm{f}}^{1} \times \mathrm{C}_{\mathrm{f}}^{2} \times \mathrm{C}^{3}{ }_{\mathrm{f}} \times \cdots \times \mathrm{C}_{\mathrm{f}}\right)^{\wedge}(1 / \mathrm{n}) \\
\mathrm{C}_{\mathrm{f}}^{\mathrm{i}}=\mathrm{C}_{\mathrm{s}}^{\mathrm{i}} / \mathrm{C}^{\mathrm{i}}{ }_{\mathrm{n}}
\end{gathered}
$$

Here, Cis: represents the contamination value of (i) metal, Cin: represents the background value of (i) metal. If the PLI value $>1$ indicates the presence of contamination, and PLI $<1$ indicates no contamination (Tomlinson, 1980). This method was applied to the element concentrations obtained from the study area (Table 8). 
Shale bekground values defined by Turekian et al. (1961) and Krauskopf et al. (1985) were used in the Pollution Load Index calculations of the study area. In the data obtained, the smallest PLI value was calculated as 0.29 (Kinalı island) and the largest PLI value was calculated as 0.90 (Zeytinburmu). The reason for the absence of pollution is considered as Bekdround values compiled from world averages that cannot represent Marmara Sea Sediments. For this reason, calculations were made again using the "Marmara Sea Element Concentration Averages" obtained in the studies performed by Yümün (2017) (Tables 8 and 9). Correlation was performed in Table 9 by giving Pollution Load Index (PLI) together with Pollution Index (PI) values.

In the calculations made by taking the average values of the element concentrations of the Marmara Sea drilling samples as the back ground, again the smallest value was found in Kinalı island (0.38), while the highest value was calculated in Zeytinburnu sample (1.16). Here, Zeytinburnu (1.16), Kumkapı (1.09) and Büyükçekmece (1.03) Pollution Load Index (PLI) values show that there is contamination because it is $>1$. It is seen that other locations are not dirty.

Table 8. Pollution load index (PLI) values calculated in the study area

\begin{tabular}{c|c|c|c|c|c|c|c|c}
\hline $\begin{array}{c}\text { Sample } \\
\text { locations }\end{array}$ & $\mathbf{Z n}$ & $\mathbf{M n}$ & $\mathbf{A s}$ & $\mathbf{C r}$ & $\mathbf{C u}$ & $\mathbf{N i}$ & $\mathbf{F e}$ & $\begin{array}{c}\text { Pollution load } \\
\text { index (PLI) }\end{array}$ \\
\hline Silivri-1 & 63.86 & 352.00 & 4.04 & 74.11 & 24.39 & 104.05 & 24425.20 & 0.61 \\
Silivri-2 & 63.49 & 358.20 & 2.61 & 82.05 & 24.30 & 105.19 & 25687.83 & 0.58 \\
Selimpaşa-1 & 54.26 & 310.30 & 3.04 & 69.63 & 21.47 & 76.71 & 23896.90 & 0.52 \\
Selimpaşa-2 & 62.28 & 358.63 & 4.14 & 81.58 & 30.76 & 110.40 & 28407.26 & 0.66 \\
Kumburgaz & 63.21 & 374.32 & 2.25 & 74.25 & 27.32 & 82.17 & 26039.22 & 0.56 \\
Büyükçekmece & 69.42 & 460.88 & 10.03 & 80.22 & 38.40 & 96.67 & 29073.15 & 0.79 \\
Gürpınar & 51.10 & 246.50 & 2.39 & 43.58 & 26.79 & 42.50 & 17021.82 & 0.41 \\
Ambarl1 & 72.40 & 252.03 & 3.01 & 49.87 & 51.81 & 45.57 & 15735.95 & 0.49 \\
Avcılar & 76.03 & 214.60 & 2.82 & 42.13 & 39.06 & 38.42 & 13430.07 & 0.43 \\
Küçükçekmece & 87.00 & 259.00 & 2.28 & 44.43 & 48.53 & 36.87 & 14044.15 & 0.46 \\
Yeşilköy & 62.23 & 170.26 & 3.46 & 86.24 & 40.17 & 25.64 & 12065.13 & 0.43 \\
Zeytinburnu & 219.80 & 288.60 & 4.75 & 197.64 & 135.40 & 42.03 & 19752.96 & 0.90 \\
Yenikap1-1 & 83.15 & 218.20 & 7.47 & 133.15 & 62.01 & 30.82 & 14065.50 & 0.62 \\
Yenikap1-2 & 65.43 & 180.25 & 4.78 & 87.00 & 40.26 & 23.75 & 17746.90 & 0.48 \\
Kumkap1-1 & 106.72 & 235.60 & 7.87 & 103.50 & 88.54 & 29.51 & 16428.50 & 0.67 \\
Kumkap1-2 & 160.47 & 225.35 & 8.62 & 174.12 & 126.44 & 33.45 & 18727.55 & 0.84 \\
Boğaziçi & 66.37 & 201.60 & 3.40 & 36.72 & 51.50 & 23.59 & 13969.60 & 0.41 \\
Haydarpaşa & 52.99 & 223.36 & 2.57 & 35.17 & 26.31 & 24.93 & 14567.36 & 0.36 \\
Üsküdar & 88.47 & 335.73 & 3.80 & 58.92 & 58.42 & 45.41 & 22336.70 & 0.60 \\
Kadıköy & 79.77 & 292.73 & 3.50 & 49.69 & 55.00 & 35.15 & 19843.67 & 0.53 \\
Kınalı Ada & 28.00 & 125.00 & 1.55 & 45.00 & 28.50 & 35.00 & 11025.12 & 0.29 \\
C-I.22 & 25.05 & 135.02 & 2.02 & 65.21 & 23.32 & 45.01 & 11567.10 & 0.33 \\
C-I.23 & 34.02 & 134.01 & 2.50 & 56.05 & 22.25 & 32.05 & 12546.21 & 0.33 \\
C-I.24 & 45.03 & 154.05 & 3.20 & 55.00 & 26.10 & 34.05 & 13456.20 & 0.38 \\
M. Ereğlisi & 42.30 & 163.20 & 23.57 & 46.10 & 9.35 & 106.40 & 20936.90 & 0.53 \\
Background of & 95.00 & 850.00 & 13.00 & 90.00 & 45.00 & 70.00 & 47000.00 & 1.00 \\
shale & & & & & & & &
\end{tabular}


Table 9. Pollution load index (PLI) values calculated in the study area

\begin{tabular}{|c|c|c|c|c|c|c|c|c|c|}
\hline $\begin{array}{c}\text { Sample } \\
\text { locations }\end{array}$ & $\mathbf{Z n}$ & Mn & As & $\mathrm{Cr}$ & $\mathbf{C u}$ & $\mathbf{N i}$ & $\mathbf{F e}$ & $\begin{array}{c}\text { Pollution load } \\
\text { index (PLI) }\end{array}$ & $\begin{array}{r}\text { Pollution } \\
\text { index (PI) }\end{array}$ \\
\hline Silivri-1 & 63.86 & 352.00 & 4.04 & 74.11 & 24.39 & 104.05 & 24425.20 & 0.78 & 0.90 \\
\hline Silivri-2 & 63.49 & 358.20 & 2.61 & 82.05 & 24.30 & 105.19 & 25687.83 & 0.75 & 0.95 \\
\hline Selimpaşa-1 & 54.26 & 310.30 & 3.04 & 69.63 & 21.47 & 76.71 & 23896.90 & 0.67 & $\underline{1.05}$ \\
\hline Selimpaşa-2 & 62.28 & 358.63 & 4.14 & 81.58 & 30.76 & 110.40 & 28407.26 & 0.85 & $\underline{1.13}$ \\
\hline Kumburgaz & 63.21 & 374.32 & 2.25 & 74.25 & 27.32 & 82.17 & 26039.22 & 0.72 & 0.88 \\
\hline Büyükçekmece & 69.42 & 460.88 & 10.03 & 80.22 & 38.40 & 96.67 & 29073.15 & $\underline{1.03}$ & $\underline{1.00}$ \\
\hline Gürpınar & 51.10 & 246.50 & 2.39 & 43.58 & 26.79 & 42.50 & 17021.82 & 0.52 & 0.66 \\
\hline Ambarl & 72.40 & 252.03 & 3.01 & 49.87 & 51.81 & 45.57 & 15735.95 & 0.64 & 0.75 \\
\hline Avcılar & 76.03 & 214.60 & 2.82 & 42.13 & 39.06 & 38.42 & 13430.07 & 0.56 & 0.63 \\
\hline Küçükçekmece & 87.00 & 259.00 & 2.28 & 44.43 & 48.53 & 36.87 & 14044.15 & 0.59 & 0.70 \\
\hline Yeşilköy & 62.23 & 170.26 & 3.46 & 86.24 & 40.17 & 25.64 & 12065.13 & 0.56 & 0.74 \\
\hline Zeytinburnu & 219.80 & 288.60 & 4.75 & 197.64 & 135.40 & 42.03 & 19752.96 & $\underline{1.16}$ & $\underline{1.32}$ \\
\hline Yenikapı-1 & 83.15 & 218.20 & 7.47 & 133.15 & 62.01 & 30.82 & 14065.50 & 0.80 & $\underline{1.04}$ \\
\hline Yenikapı-2 & 65.43 & 180.25 & 4.78 & 87.00 & 40.26 & 23.75 & 17746.90 & 0.62 & $\overline{0.74}$ \\
\hline Kumkapı -1 & 106.72 & 235.60 & 7.87 & 103.50 & 88.54 & 29.51 & 16428.50 & 0.87 & 0.95 \\
\hline Kumkapı -2 & 160.47 & 225.35 & 8.62 & 174.12 & 126.44 & 33.45 & 18727.55 & $\underline{1.09}$ & $\underline{1.27}$ \\
\hline Boğaziçi & 66.37 & 201.60 & 3.40 & 36.72 & 51.50 & 23.59 & 13969.60 & $\overline{0.53}$ & $\overline{0.61}$ \\
\hline Haydarpaşa & 52.99 & 223.36 & 2.57 & 35.17 & 26.31 & 24.93 & 14567.36 & 0.46 & $\underline{1.15}$ \\
\hline Üsküdar & 88.47 & 335.73 & 3.80 & 58.92 & 58.42 & 45.41 & 22336.70 & 0.78 & $\overline{0.79}$ \\
\hline Kadıköy & 79.77 & 292.73 & 3.50 & 49.69 & 55.00 & 35.15 & 19843.67 & 0.68 & 0.72 \\
\hline Kınalı Ada & 28.00 & 125.00 & 1.55 & 45.00 & 28.50 & 35.00 & 11025.12 & 0.38 & 0.33 \\
\hline C-I.22 & 25.05 & 135.02 & 2.02 & 65.21 & 23.32 & 45.01 & 11567.10 & 0.42 & 0.36 \\
\hline C-I.23 & 34.02 & 134.01 & 2.50 & 56.05 & 22.25 & 32.05 & 12546.21 & 0.42 & 0.36 \\
\hline C-I.24 & 45.03 & 154.05 & 3.20 & 55.00 & 26.10 & 34.05 & 13456.20 & 0.48 & 0.38 \\
\hline M. Ereğlisi & 42.30 & 163.20 & 23.57 & 46.10 & 9.35 & 106.40 & 20936.90 & 0.68 & 0.73 \\
\hline $\begin{array}{l}\text { Main value of } \\
\text { Marmara Sea }\end{array}$ & 88.54 & 388.9 & 18.05 & 62.17 & 30.3 & 78.63 & 25211 & 1.00 & 1.00 \\
\hline
\end{tabular}

\section{Pollution index (PI)}

To make the results of geochemical analysis more visual and interpretable, the Pollution Index (PI) method, as defined by Yümün (2017), was applied. PI values are the proportionality coefficients containing the arithmetic mean of the values of each element obtained by geochemical analysis together with the values obtained from the previous studies in the Sea of Marmara. PI was calculated using the following equation (Eq. 5):

$$
\mathrm{PI}=\left[\left(\mathrm{MV}_{1} / \mathrm{MV}_{\mathrm{avg}}\right)+\left(\mathrm{MV}_{2} / \mathrm{MV}_{\mathrm{avg}}\right)+\cdots+\left(\mathrm{MV}_{\mathrm{n}} / \mathrm{MV}_{\mathrm{avg}}\right)\right] / \mathrm{n}
$$

The parameters used in the equation are: PI: Pollution Index, $\mathrm{MV}_{1}$ : Heavy metal

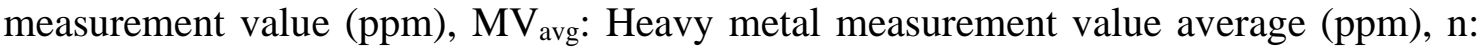
The number of the heavy metals measured. PI maps were produced by Kriging method (Krige, 1951) using PI values. In this map, PI values are defined as 0-0.50 (max. clean zone), 0.5- 0.85 (clean zone), 0.85-1.00 (clean-dirty transition zone), 1.00-1.15 
(polluted zone), and PI $>1.15$ (high polluted zone). In areas where heavy metal concentrations are high, PI values are higher than critical values $(\mathrm{PI}=1)$ and are defined as dirty areas.

The number of genera, species and individuals of foraminifera is quite low in the places where pollution is high. It is thought that the low number of foraminifera samples in samples taken from Küçükçekmece, Büyükçekmece, Ambarlı and Avcılar regions are due to ship traffic and discharge of domestic and industrial wastewater into the sea (Table 10; Figs. 4 and 5).

Table 10. Values of pollution index (PI)

\begin{tabular}{c|c|c|c}
\hline Sample No & $\begin{array}{c}\text { Pollution index } \\
\text { (PI) }\end{array}$ & Sample No & $\begin{array}{c}\text { Pollution index } \\
\text { (PI) }\end{array}$ \\
\hline Silivri-1 & 0.898 & Yenikapı-2 & 0.741 \\
Silivri-2 & 0.947 & Kumkap1-1 & 0.954 \\
Selimpaşa-1 & $\underline{\mathbf{1 . 0 4 9}}$ & Kumkap1-2 & $\underline{\mathbf{1 . 2 7 0}}$ \\
Selimpaşa-2 & $\underline{\mathbf{1 . 1 3 1}}$ & Boğaziçi & 0.613 \\
Kumburgaz & 0.881 & Haydarpaşa & $\underline{\mathbf{1 . 1 5 2}}$ \\
Büyükçekmece & 0.996 & Üsküdar & 0.791 \\
Gürpınar & 0.655 & Kadı̈öy & 0.718 \\
Ambarlı & 0.754 & Kınalı Ada & 0.326 \\
Avcılar & 0.631 & C-I.22 & 0.358 \\
Küçükçekmece & 0.696 & C-I.23 & 0.357 \\
Yeşilköy & 0.741 & C-I.24 & 0.384 \\
Zeytinburnu & $\underline{\mathbf{1 . 3 1 9}}$ & M. Ereğlisi & 0.729 \\
Yenikapi-1 & $\underline{\mathbf{1 . 0 4 4}}$ & & \\
Marmara Sea & $\underline{0.809}$ & The main values of Marmara & $\underline{\mathbf{1 . 0 0 0}}$ \\
\hline
\end{tabular}

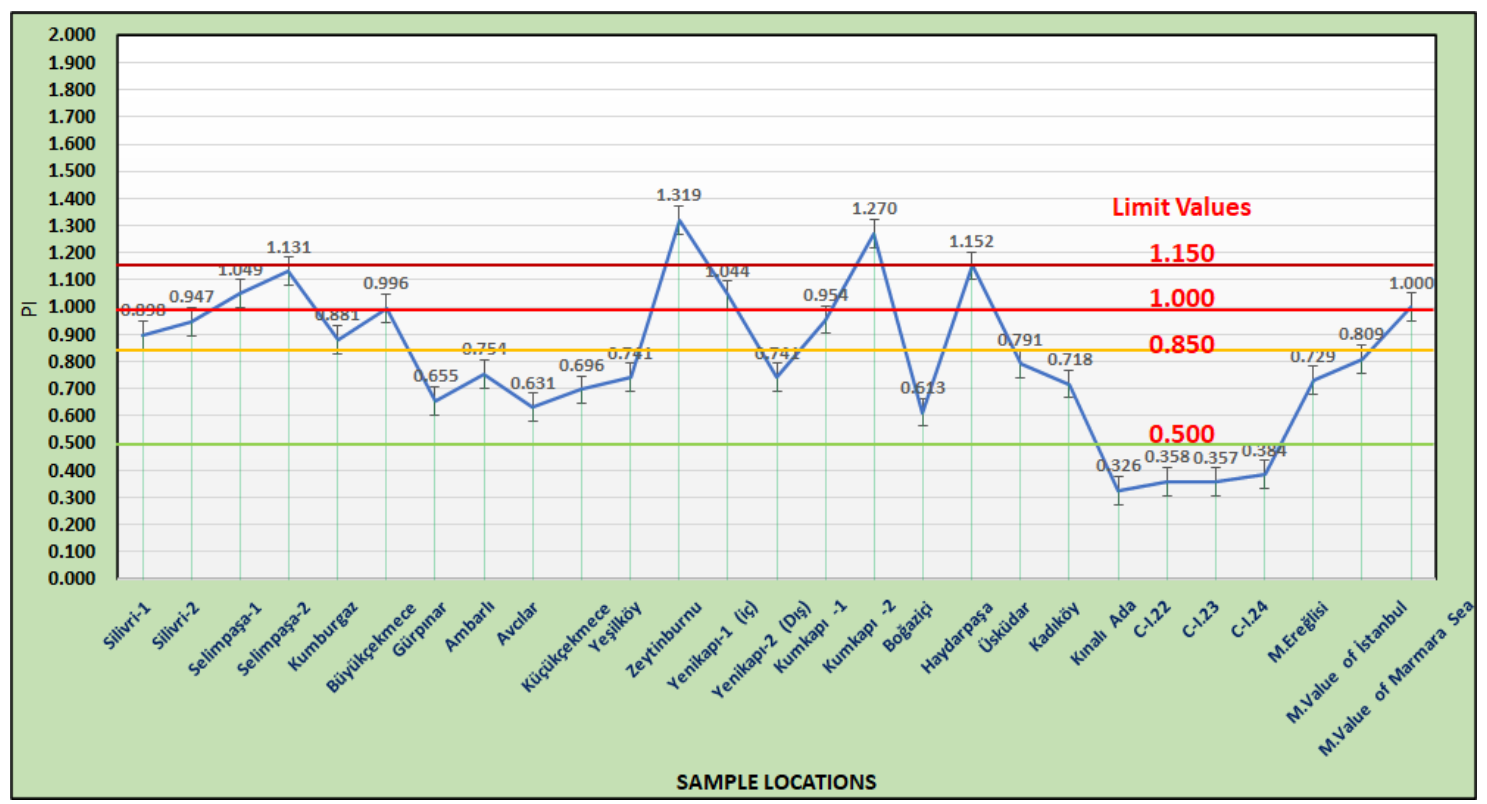

Figure 4. Pollution index of Marmara Sea in Istanbul 


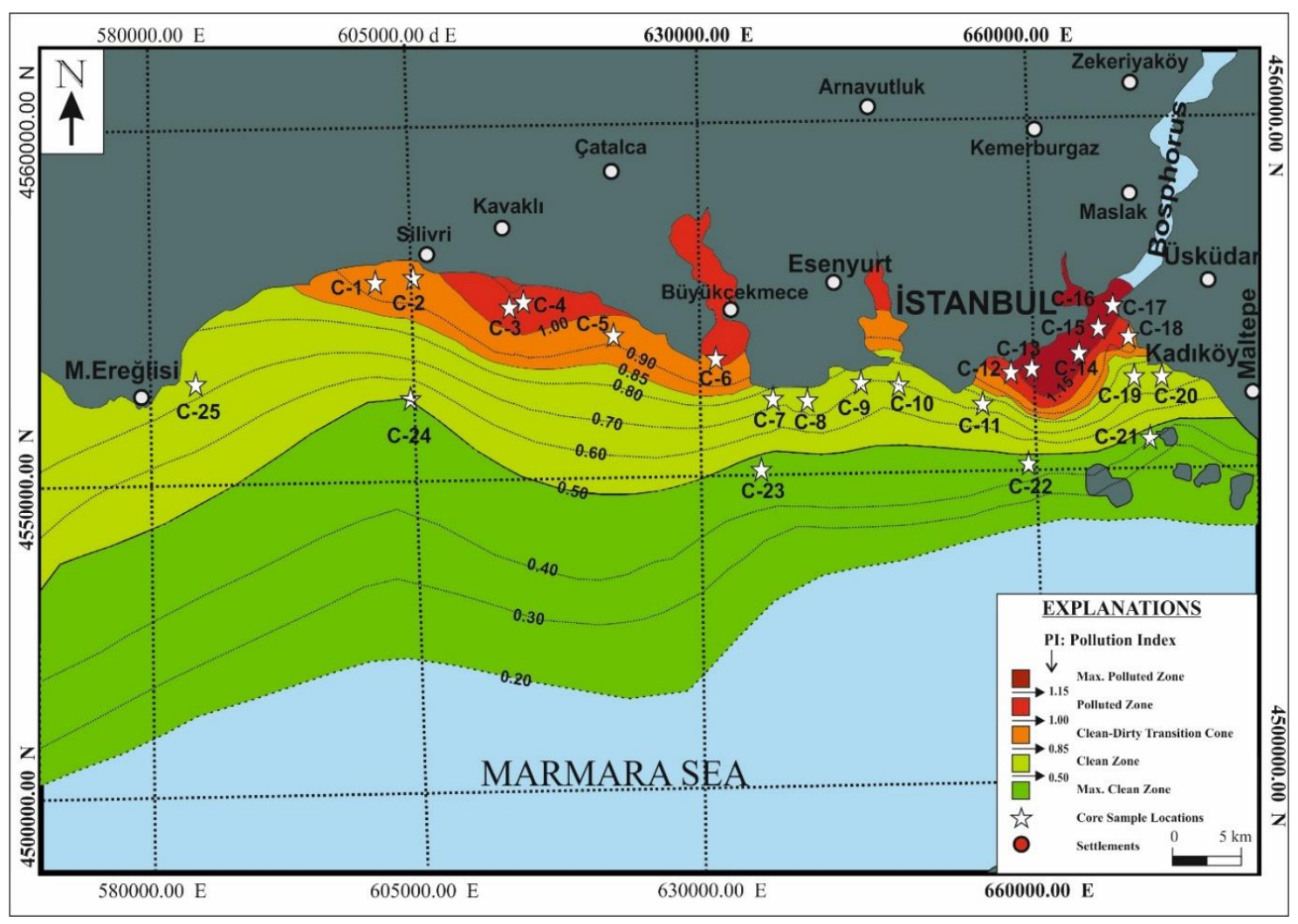

Figure 5. Pollution index (PI) map of the study area (North Marmara)

\section{Foraminifer communities}

Sediment core samples taken from the study area were divided into $10 \mathrm{~cm}$ sections and granulometric analysis was conducted for each sample. In the granulometric analysis, the granules remaining on the $63 \mu \mathrm{m}$ sieve were examined using a stereo-zoom microscope. The foraminifera were extracted, and micro-photographs were taken. In this study, a rich foraminifera group consisting of 15 genera and 30 species was identified (Table 11; Figs. 6-9). Color changes were observed in Ammonia compacta. The changes in the foraminifer shells were investigated by examining the concentrations of toxic elements at the levels where morphological changes occurred in the foraminifer shells. Significant color changes were observed in the foraminiferal shells. The shells demonstrated different shades, ranging from yellowish brown to black. To determine the causes of these discolorations, surface element analysis was conducted on the shells using a scanning electron microscope (SEM) (Fig. 10). The shell structures of the foraminifera are limestone $(\mathrm{CaCO} 3)$, agglutinate (Rock Pieces) and silica ( $\mathrm{SiO} 2)$. During the growth of foraminifer, $\mathrm{CaCO} 3$ and $\mathrm{SiO} 2$, which are dissolved in water, are chemically added to the shell structure. During the growth of the shells, it undergoes color change by adding elements that are in the form of molten or ions in the water. In places where the $S$ values were high, the color had turned into dark grey-black colors. At high Fe and Mn values, the color turned yellow-yellowish brown.

The numbers given in Table 11 give the numbers of foraminifera species found in $10 \mathrm{~g}$ of sediment. The high number of foraminifera species indicates that the environment conditions are ideal for micro-living life, and the low number of foraminifera species indicates that the environment is not ideal for the habitat. 
Table 11. Foraminifer communities identified in the study area

\begin{tabular}{|c|c|c|c|c|c|c|c|c|c|c|c|c|c|c|c|c|c|c|c|c|}
\hline & 紊 & 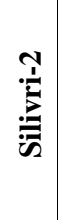 & 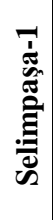 & 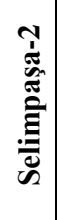 & 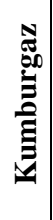 & 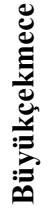 & 胥 & 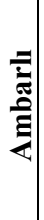 & $\frac{\grave{z}}{\bar{z}}$ & 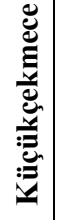 & 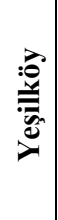 & 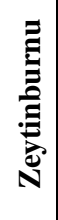 & 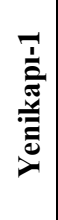 & 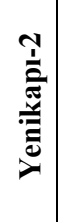 & 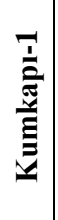 & 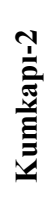 & 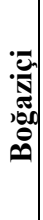 & 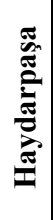 & 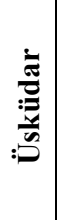 & 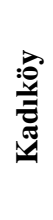 \\
\hline Adelosina cliarensis & & & & & & & & & & & & & & & & 3 & & 10 & 10 & 4 \\
\hline Adelosina duthersi & 2 & 1 & 4 & 2 & & & 4 & & 7 & & & & & & & & & & & \\
\hline $\begin{array}{c}\text { Adelosina } \\
\text { mediteranensis }\end{array}$ & 1 & & & & & & & & 1 & & & & & & & & & 2 & & \\
\hline \multicolumn{21}{|l|}{ Adelosina partschi } \\
\hline Ammonia compacta & 47 & 40 & 39 & 30 & 19 & 6 & 23 & 8 & 68 & 22 & 14 & 33 & 25 & 11 & 17 & 18 & 1 & 60 & 38 & 28 \\
\hline $\begin{array}{c}\text { Ammonia } \\
\text { parkinsoniana }\end{array}$ & & & & & & & & & & & & & & & & & & 7 & 8 & \\
\hline Ammonia tepida & 3 & 2 & 2 & 5 & & & 1 & & 8 & & & 5 & & & 1 & & 1 & 9 & 7 & \\
\hline $\begin{array}{c}\text { Cribroelphidium } \\
\text { poeyanum }\end{array}$ & & & 2 & & & & & & & & & & 2 & & & & & & 1 & \\
\hline Cycloforina contorta & & & 3 & 6 & & & & & & & & & 6 & 2 & & & 1 & & & \\
\hline Cycloforina villafrance & & & & & & & 3 & & 7 & & & & 8 & & & & & & & \\
\hline Elphidium crispum & 36 & 40 & 50 & 45 & 4 & 4 & 46 & 5 & 50 & 15 & 19 & 40 & 40 & 7 & 5 & 20 & & 15 & 32 & 13 \\
\hline $\begin{array}{c}\text { Elphidium } \\
\text { complanatum }\end{array}$ & & & & & & & 5 & 4 & 2 & & & & & & & 3 & & & & \\
\hline $\begin{array}{c}\text { Eponides } \\
\text { concomeratus }\end{array}$ & 1 & & 10 & 6 & & 1 & & & & & & & 11 & 3 & & & 1 & & 8 & 5 \\
\hline Lachlanella bicornis & 1 & & & & & & & & & & 1 & & 4 & & & & & 2 & & \\
\hline Lobatula lobatula & 3 & 2 & 26 & 15 & 1 & & 4 & 2 & 14 & 7 & & 19 & 16 & 2 & 1 & 4 & 1 & 18 & 15 & 13 \\
\hline Miliolinella subrotunda & & & 3 & & & & 3 & & & & & 2 & 5 & & & 3 & & 3 & 1 & 11 \\
\hline \multicolumn{21}{|l|}{ Miliolinella circularis } \\
\hline \multicolumn{21}{|l|}{$\begin{array}{c}\text { Pseudotriloculina } \\
\text { oblonga }\end{array}$} \\
\hline \multicolumn{21}{|l|}{ Pyrgo elongata } \\
\hline Pygro Inornata & & 2 & 2 & & 2 & & & & & & & & & & & & & & & \\
\hline $\begin{array}{l}\text { Plonorbulina } \\
\text { mediterranensis }\end{array}$ & & & & & & & & & 1 & 1 & & & & & & & & & & \\
\hline \multicolumn{21}{|l|}{$\begin{array}{c}\text { Quinqueloculina } \\
\text { bidentata }\end{array}$} \\
\hline $\begin{array}{l}\text { Quinqueloculina } \\
\text { jugosa }\end{array}$ & 1 & & 3 & 4 & & & & 1 & 8 & & 1 & & & & & & 1 & & 4 & \\
\hline \multicolumn{21}{|l|}{$\begin{array}{l}\text { Quinqueloculina } \\
\text { lamarckiana }\end{array}$} \\
\hline $\begin{array}{c}\text { Quinqueloculina } \\
\text { laevigata }\end{array}$ & & & & & & & & & & & & 3 & & & & & & & & 9 \\
\hline $\begin{array}{l}\text { Quinqueloculina } \\
\text { seminula }\end{array}$ & & & 9 & 12 & & 1 & 3 & 1 & & & 1 & 5 & 23 & 3 & 4 & 7 & 4 & 31 & 26 & 26 \\
\hline \multicolumn{21}{|l|}{$\begin{array}{c}\text { Quinqueloculina } \\
\text { stelligera }\end{array}$} \\
\hline Rosalina bradyi & & & 2 & & & & & & & & & & 3 & & & & & & & \\
\hline Spiriloculina excavata & & & 2 & 4 & 1 & & 1 & & 6 & & & & 6 & & & 1 & & & & \\
\hline Textularia bocki & & & & & & & & & & & & & & & & & & & & \\
\hline
\end{tabular}




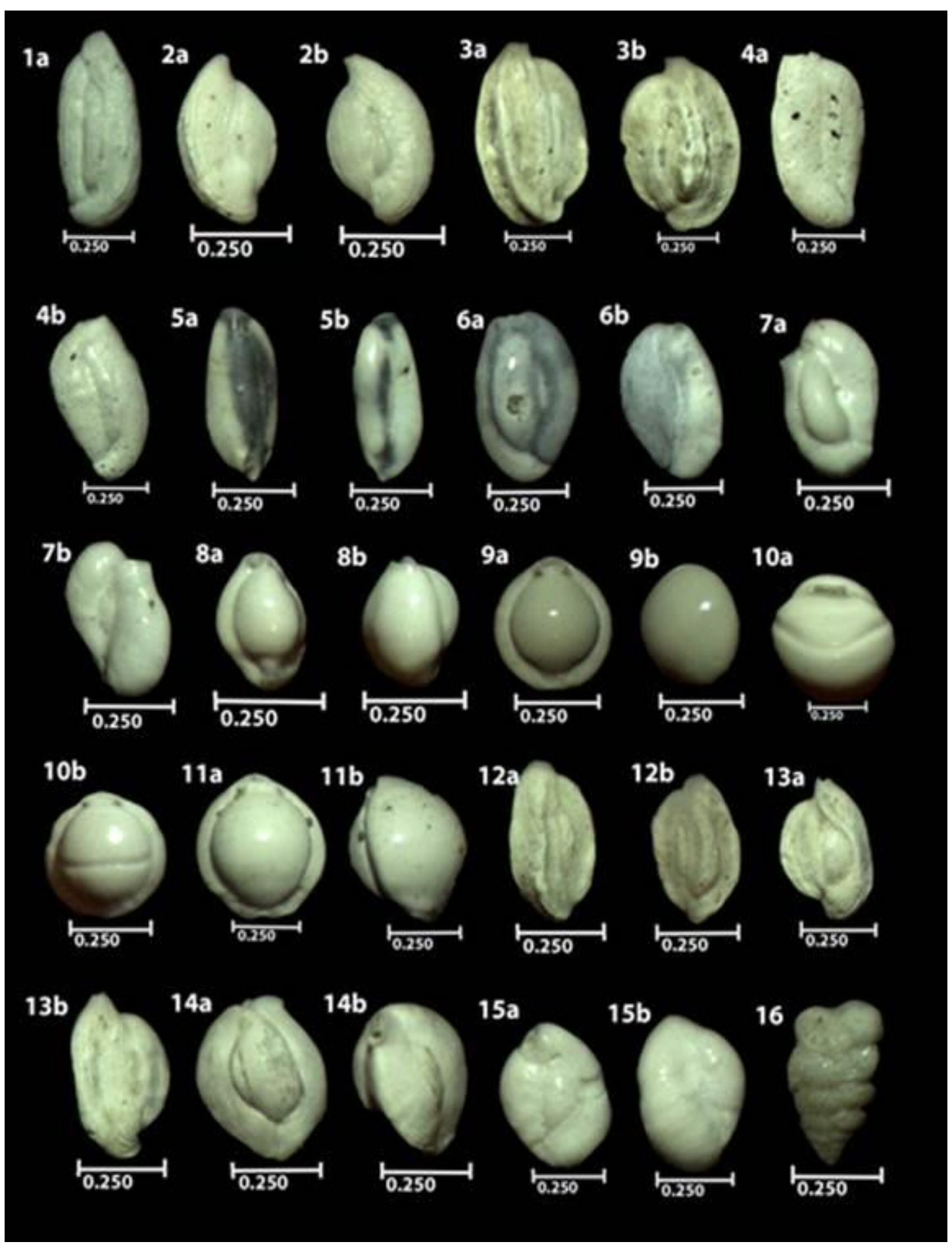

Figure 6. la. Quinqueloculina jugosa, Cushman (Ambarl-A)2a,b. Adelosina duthersi (Avcllara), 3a,b. Cycloforina contorta, (d'Orbigny), Boğaziçi-2, 4a,b. Cycloforina villafrance, (le Calvez, $J$ \& Y.), Gürpinar-2, 5a,b. Pseudotriloculina oblonga, (Montagu), Haydarpaşa-1, 6a,b. Miliolinella subrotunda, (Montagu), Haydarpaşa-2, 7a,b. Miliolinella subrotunda, (Montagu),

Kumkapt-2/1, 8a,b. Pygro inornata, (d'Orbigny), Selimpaşa-1, 9a,b. Pygro inornata, (d'Orbigny), Selimpaşa-1, 10a,b. Pygro inornata, (d'Orbigny), Selimpaşa-2, 11a,b. Pygro inornata, (d'Orbigny), Selimpaşa-2, 12a,b. Cycloforina contorta, (d'Orbigny), Selimpaşa-1, 13a,b. Adelosina mediteranensis, (le Calvez, J \& Y.), Silivri-1, 14a,b. Lachlanella bicornis, (Walker \& Jacob), Silivri-2, 15a,b. Miliolinella sp. Yenikapı-1/1, 16. Textularia bocki, Höglund, Haydarpaşa-2. (scale lengths are $\mathrm{mm}$ ) 


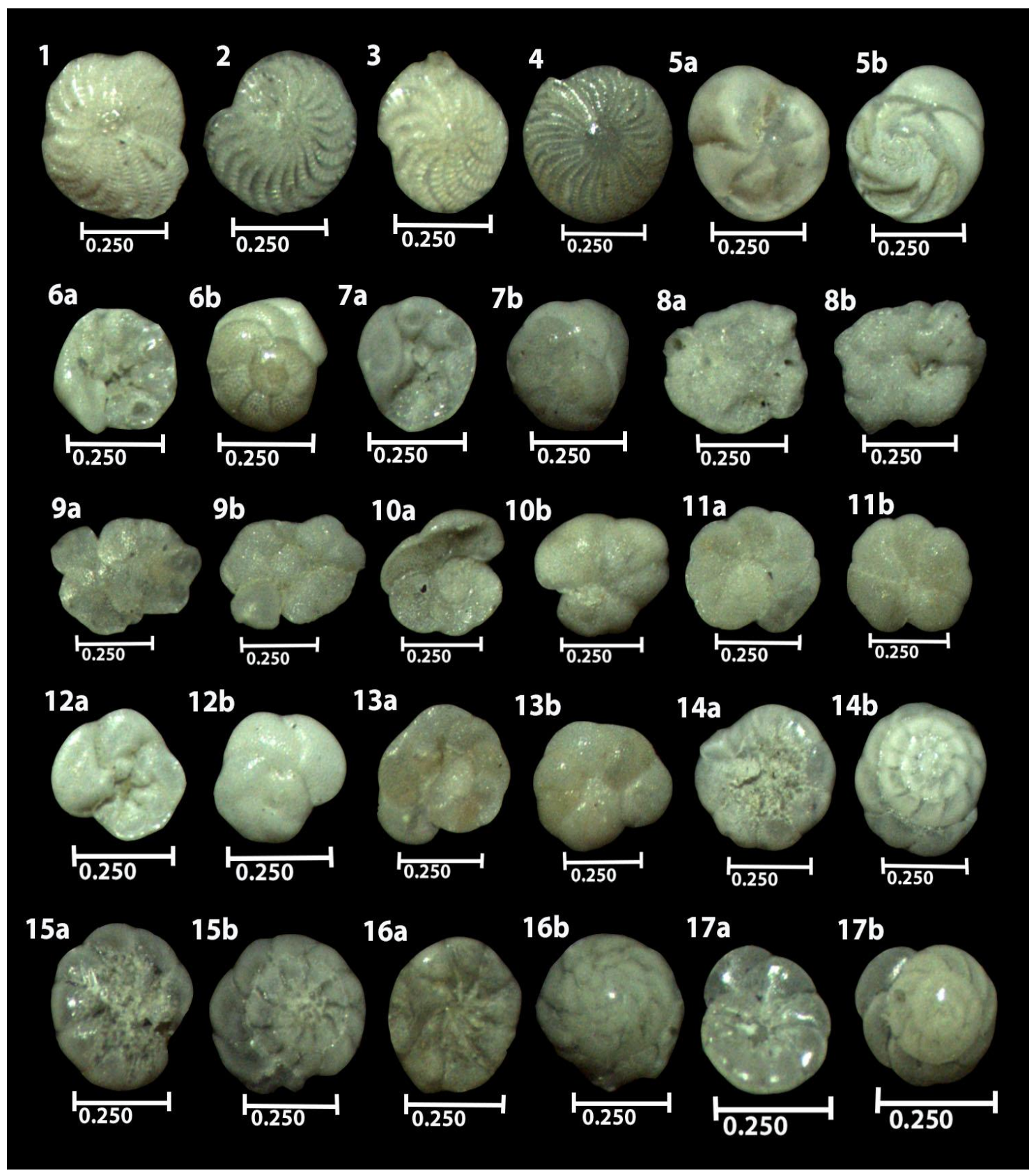

Figure 7. 1. Elphidium crispum, (Linne), Ambarl-1, 2. Elphidium crispum, (Linne), Avcılar-4, 3. Elphidium crispum, (Linne), Büyükçekmece-1, 4. Elphidium crispum, (Linne), Kumkapl-,2/2, 5a,b. Eponides concomeratus, (Williamson). Boğaziçi-1, 6a,b. Ammonia tepida, (Cushman), Selimpaşa-1, 7a,b. Ammonia tepida, (Cushman), Yenikapı-1/1, 8a, b.

Lobatula lobatula (Walker \& Jacob), Avcllar-1, 9a,b. Lobatula lobatula (Walker \& Jacob),Boğaziçi-1, 10a,b. Lobatula lobatula (Walker \& Jacob), Gürpınar-2, 11a,b. Lobatula lobatula (Walker \& Jacob), Haydarpaşa-1, 12a,b. Lobatula lobatula (Walker \&

Jacob),Haydarpaşa-2, 13a,b. Lobatula lobatula (Walker \& Jacob), Kumkapı-2/1, 14a,b. Ammonia compacta, Hofker, Silivri-1, 15a,b. Ammonia compacta, Hofker Avcılar-4, 16a,b. Ammonia tepida, (Cushman), Gürpınar-1, 17a,b. Ammonia tepida, (Cushman), Bostancı-2.

(scale lengths are $\mathrm{mm}$ ) 


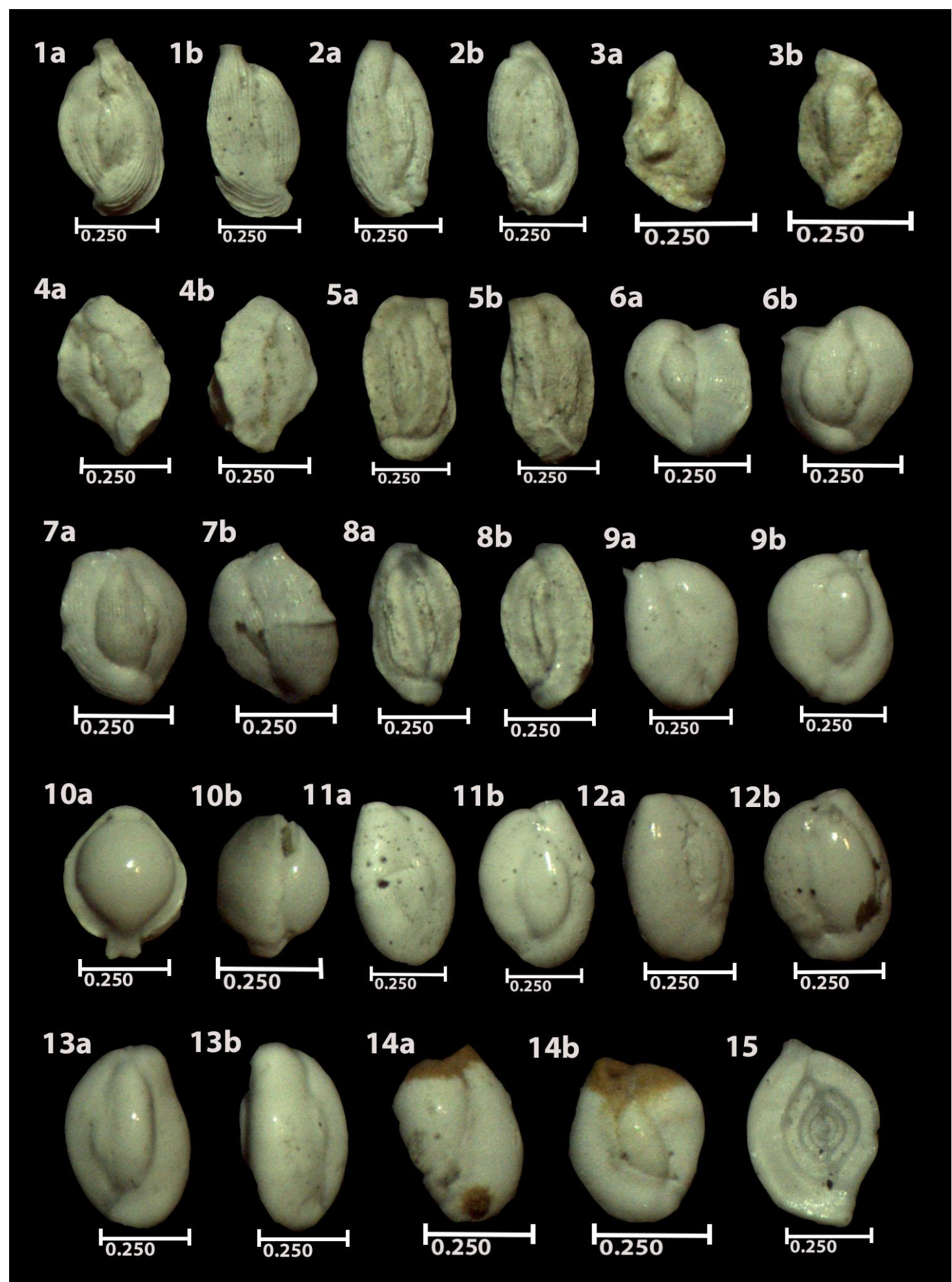

Figure 8. 1a,b: Adelosina partschi (Avcllar - $b$ ), $2 a, b$ : Sycloforina villafrance (Avcllar-b), 3 $a, b$ : Quinqueloculina stalkeri (Kadıköy-a), 4a,b: Quinqueloculina bidentata (Maltepe-a), $5 a, b$ : Quinqueloculina bidentata (Selimpaşa-c), 6 a,b. Quinqueloculina lamarckiana (Yenikapı-1-b), 7 a,b: Quinqueloculina lamarckiana (Yeşilköy-b), 8 a,b: Quinqueloculina stelligera (Yenikapı1-b), 9 a,b: Miliolinella circularis (Zeytinburnu-a), 10 a,b: Pyrgo elongata (Selimpaşa-c), 11 a,b: Quinqueloculina laevigata (Yenikapt-1-b), 12 a,b: Quinqueloculina laevigata (Yenikapt-1c), 13 a,b: Quinqueloculina laevigata (Yenikapı-2-a), 14 a,b: Spiriloculina excavata (Yeşilköyb), 15 : Spiriloculina excavata (Yenikapt-1-b). (scale lengths are mm) 


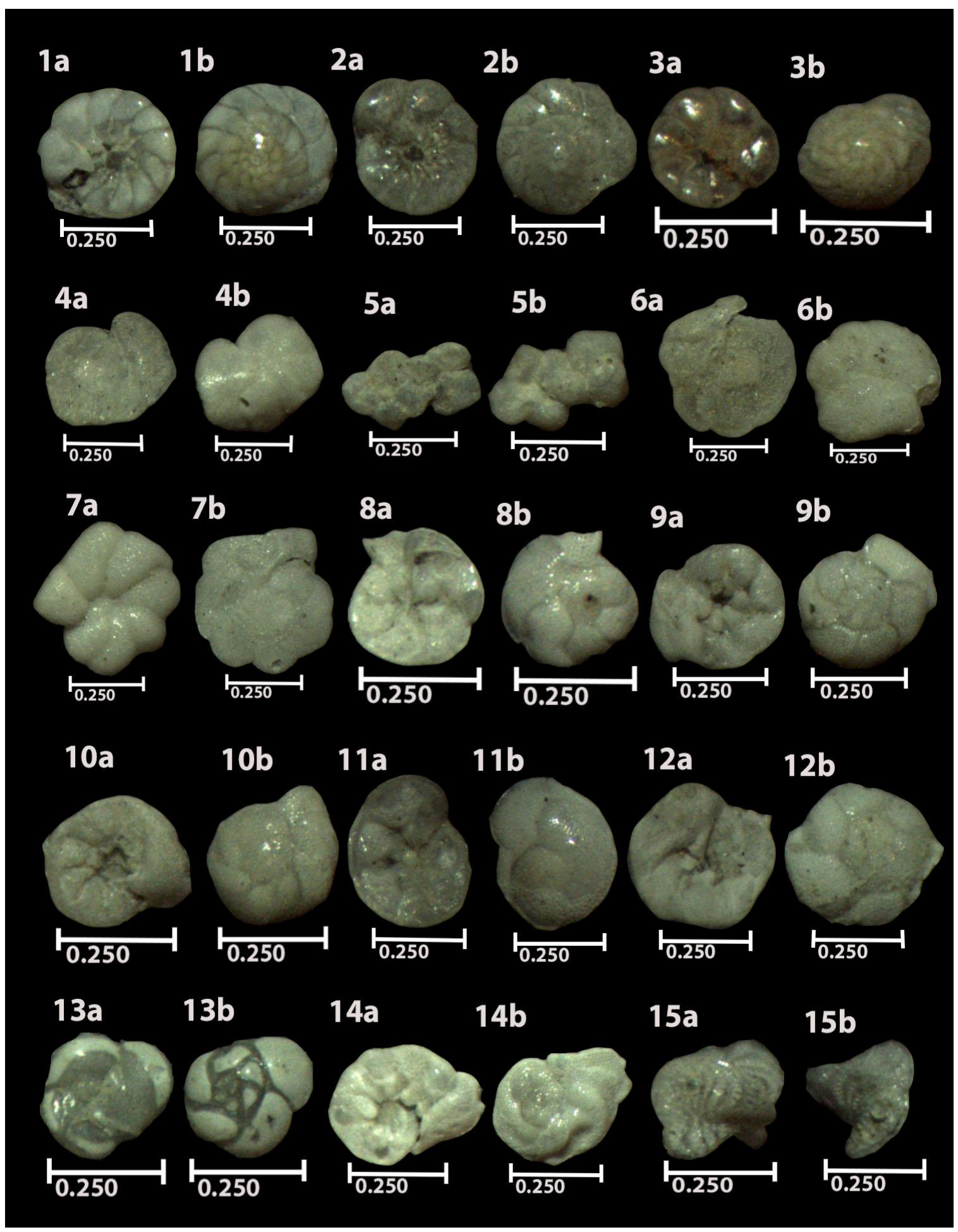

Figure 9. 1 a,b: Ammonia parkinsoniana (Avcllar-b), 2a,b: Ammonia parkinsoniana (Maltepea), 3 a,b: Ammonia parkinsoniana (Zeytiburnu-a), 4 a,b: Lobatula lobatula (Avcllar-b), $5 a, b$ : Lobatula lobatula (Kadlköy-a), 6 a,b: Lobatula lobatula (Maltepe-a), 7 a,b: Lobatula lobatula (Yenikapl-1-c), 8 a,b: Rosalina globularis (Avcllar-b), 9 a,b: Rosalina globularis (Kadıköy-a), 10 a,b: Rosalina globularis (Selimpaşa-c), 11 a,b: Rosalina globularis (Yenikapl-1b), $12 a, b$; Rosalina globularis (Yanikapt-1c), $13 a$,b: Eponides concameratus (Zeytinburna-a), $14 a, b$; Lobatula lobatula (Üsküdar-d), 15 a,b: Elphidium crispum (Selimpaşa-d). (scale lengths are 


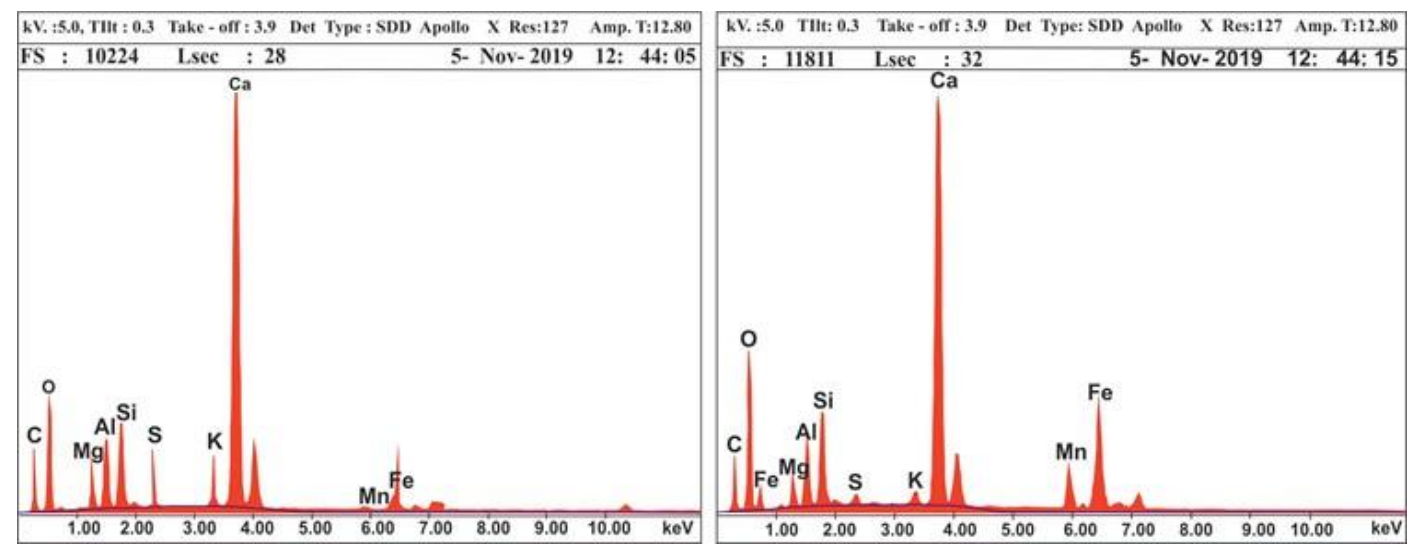

Figure 10. Graphs of surface element analysis

\section{Conclusion}

In this study, the effects of heavy metals on the sediments of the Istanbul part of Marmara Sea and the effects of pollution on benthic foraminifers were assessed. Benthic foraminifer assemblages and geochemical properties of the samples were determined in the study.

Elemental analysis of (Fe, Zn, Al, Mn, As, B, Co, Cr, Cu, Ni, Sb, Na, Mg, K, Ca, P, $\mathrm{Pb}, \mathrm{Hg}, \mathrm{Cd}, \mathrm{Ag}, \mathrm{Bi}, \mathrm{Cd}, \mathrm{Mo}, \mathrm{Pb}, \mathrm{Pt}, \mathrm{Sn}, \mathrm{Se}$, and $\mathrm{Hg}$ ) sediments from the sea was conducted using ICP-OES. The concentrations of some elements (especially for Fe, Mn, $\mathrm{Ti}, \mathrm{Zn}$, and $\mathrm{Cr}$ ) were found to be very high in locations where ship traffic and domestic and industrial discharges are high.

Enrichment Factor (EF), Contamination factor (Cfi) (Hakanson, 1980), Pollution Load Index (PLI) and Pollutin Index (PI) (Yümün, 2017) were applied to the geochemical analysis results of sediment samples taken in the study area. According to enrichment factor (EF) and Contamination factor (Cfi) methods, enrichment and contamination are observed in terms of some elements. According to the enrichment factor, $\mathrm{Cu}$ (3.1), Ni (2.4) in Büyükçekmece, EFCu (7.6), EFZn (5.9) in Zeytinburnu, EFCu (6.0), EFZn(3.4) in Kumkap1-1, $\operatorname{EFCu(7.5)~ve~} \operatorname{EFZn(4.5)~in~Kumkap1-2~values~are~>~3,~according~to~this~}$ $\mathrm{Cu}$ and $\mathrm{Zn}$ are high and very high enrichment. In the analysis made according to the contamination factor, the values are determined of Kumkap1-1 CfCu (1.90) and CfZn (1.12), Kumkapı-2 CfCu (2.80) and CfZn (1.60); Zeytinburnu CfCu (3.0) and CfZn (2.3); It was obtained as $\mathrm{CfCu}(1.80)$ and $\mathrm{Cf} \mathrm{Ni}$ (1.30) in Büyükçekmece. According to these results, the locations appear to be contaminated in terms of $\mathrm{Cu}, \mathrm{Zn}$ and $\mathrm{Ni}$. According to four analysis methods, medium-high level of impurities were detected in these 3 (Büyükçekmece, Zeytinburnu and Kumkapı) locations.

In the Pollution Load Index (PLI) calculations, both the Shale values defined by Turekian et al. (1961) and Krauskopf et al. (1985), and the drilling concentration samples compiled from Yümün (2017) and Yümün and Kam (2019) were used as background elements. Since the shale values do not represent the Marmara region, no pollution was observed in this method. In the PLI calculations made using the Marmara Sea element concentration averages, pollution is observed in some locations. These second calculation values are correlated with the Pollution Index (PI) values in Table 9, and common dirty points (Büyükçekmece, Zeytinburnu and Kumkapı) are determined according to both methods. The Pollution Index (PI) values of these locations (Selimpaşa (1.131), Zeytinburnu (1.319), Yenikapı (1.044), Kumkapı (1.270), and 
Haydarpaşa Port (1.152) were also high. A contamination zone map was prepared using the Kriging method on the PI values, summarizing heavy metal concentrations of each sampling point of the study area. This pollution zone map has been useful in terms of visualizing and interpreting the pollution capacity of the study area.

In locations where heavy metal concentrations were high, the number of foraminifer individuals was very low. In addition, color changes and morphological defects were detected in most of the locations.

Here, while Pollution Load Index (PLI) and Pollution Index (PI) analyze the final impurities formed by the contribution of all elements, Enrichment factor (EF) and Contamination factor (Cfi) determine the polluting elements in the environment. The application and interpretation of these methods together in environmental analysis will yield useful results.

In addition, in order to identify possible lithological units that may cause metal accumulation in the bottom sediments, the geological map of the Northeast Marmara Drainage Area was compiled and the lithological units that surfaced in the coastal areas adjacent to these areas were examined. Summaries of the results of the Pollution Index, Enrichment Factor, Contamination Factor and Pollution Load Index were given in Table 12. Dirty locations (such as Zeytinburnu) in all indexes are marked in bold in the table.

Table 12. The correlations of pollution index, enrichment factor, contamination factor and pollution load index

\begin{tabular}{|c|c|c|c|c|c|c|c|c|c|}
\hline \multirow{3}{*}{$\begin{array}{c}\begin{array}{c}\text { Core } \\
\text { sample No }\end{array} \\
\text { C-1 }\end{array}$} & \multirow{3}{*}{\begin{tabular}{|c|} 
Core sample location \\
Silivri-1 \\
\end{tabular}} & \multicolumn{2}{|c|}{ Pollution index } & \multicolumn{2}{|c|}{ Enrichment factor } & \multirow{2}{*}{\multicolumn{2}{|c|}{ Contamination factor }} & \multicolumn{2}{|c|}{$\begin{array}{c}\text { Pollution load } \\
\text { index }\end{array}$} \\
\hline & & \multirow{2}{*}{$\begin{array}{c}\text { (PI) } \\
0.898\end{array}$} & \multirow{2}{*}{$\frac{\text { Exp. }}{C D}$} & \multirow{2}{*}{$\begin{array}{c}\text { EF } \\
\mathrm{EF}_{\mathrm{Ni}}=3.10\end{array}$} & \multirow{2}{*}{$\begin{array}{c}\text { Exp. } \\
\text { VE }\end{array}$} & & & PLI & \\
\hline & & & & & & $\mathrm{C}_{\mathrm{f}} \mathrm{Ni}=\underline{1.50}$ & MC & 0.61 & $\mathrm{NC}$ \\
\hline $\mathrm{C}-2$ & Silivri-2 & 0.947 & $\mathrm{CD}$ & $\mathrm{EF}_{\mathrm{Ni}}=2.90$ & LE & $\mathrm{C}_{\mathrm{f}} \mathrm{Ni}=\underline{\overline{1.50}}$ & MC & 0.58 & $\mathrm{NC}$ \\
\hline $\mathrm{C}-3$ & Selimpaşa-1 & $\underline{1.049}$ & $\mathrm{P}$ & $\mathrm{EF}_{\mathrm{Ni}}=2.30$ & LE & $\mathrm{C}_{\mathrm{f}} \mathrm{Ni}=\underline{1.10}$ & MC & 0.52 & $\mathrm{NC}$ \\
\hline C-4 & Selimpaşa-2 & $\underline{1.131}$ & $\mathrm{P}$ & $\mathrm{EF}_{\mathrm{Ni}}=2.80$ & LE & $\mathrm{C}_{\mathrm{f}} \mathrm{Cu}=\underline{1.80}$ & MC & 0.66 & $\mathrm{NC}$ \\
\hline C-5 & Kumburgaz & 0.881 & $\mathrm{CD}$ & $\mathrm{EF}_{\mathrm{Cu}}=3.10$ & VE & $\mathrm{C}_{\mathrm{f}} \mathrm{Cu}=\underline{1.70}$ & MC & 0.56 & $\mathrm{NC}$ \\
\hline C-6 & Büyükçekmece & 0.996 & $\mathrm{CD}$ & $\mathrm{EF}_{\mathrm{Cu}}=3.10$ & VE & $\mathrm{C}_{\mathrm{f}} \mathrm{Cu}=\underline{1.80}$ & MC & 0.79 & $\mathrm{NC}$ \\
\hline $\mathrm{C}-7$ & Gürpınar & 0.655 & $\mathrm{C}$ & $\mathrm{EF}_{\mathrm{Cu}}=5.30$ & $\mathrm{HE}$ & $\mathrm{C}_{\mathrm{f}} \mathrm{Cu}=\underline{1.80}$ & MC & 0.41 & $\mathrm{NC}$ \\
\hline $\mathrm{C}-8$ & Ambarl & 0.754 & $\mathrm{C}$ & $\mathbf{E F}_{\mathrm{Cu}}=\mathbf{3 . 7}$ & VE & $C_{\mathrm{f}} \mathrm{Cu}=\underline{\underline{1.15}}$ & MC & 0.49 & $\mathrm{NC}$ \\
\hline C-9 & Avcilar & 0.631 & $\mathrm{C}$ & $\mathrm{EF}_{\mathrm{Cu}}=3.50$ & $\mathrm{VE}$ & $\mathrm{C}_{\mathrm{f}} \mathrm{Cu}=\overline{0.93}$ & $\mathrm{LC}$ & 0.43 & $\mathrm{NC}$ \\
\hline $\mathrm{C}-10$ & Küçükçekmece & 0.696 & $\mathrm{C}$ & $\mathrm{EF}_{\mathrm{Zn}}=4.38$ & $\mathrm{VE}$ & $\mathrm{C}_{\mathrm{f}} \mathrm{Cu}=0.98$ & $\mathrm{LC}$ & 0.46 & $\mathrm{NC}$ \\
\hline $\mathrm{C}-11$ & Yeşilköy & 0.741 & $\mathrm{C}$ & $\mathrm{EF}_{\mathrm{Cu}}=7.90$ & $\mathrm{HE}$ & $\mathrm{C}_{\mathrm{f}} \mathrm{Cu}=1.91$ & MC & 0.43 & $\mathrm{NC}$ \\
\hline$\underline{\mathrm{C}-12}$ & Zevtinburnu & $\underline{1.319}$ & $\underline{\mathrm{HP}}$ & $\underline{E F}_{\mathrm{Cu}}=7.60$ & $\underline{\mathrm{HE}}$ & $\underline{\mathrm{C}}_{\mathrm{f}} \underline{\mathrm{Cu}=3.00}$ & $\underline{\mathrm{MC}}$ & 0.90 & $\mathrm{NC}$ \\
\hline C-13 & Yenikapı-1 & 1.044 & $\mathrm{P}$ & $\mathrm{EF}_{\mathrm{Cu}}=4.90$ & $\mathrm{VE}$ & $\mathrm{C}_{\mathrm{f}} \mathrm{Cu}=0.89$ & $\mathrm{LC}$ & 0.62 & $\mathrm{NC}$ \\
\hline C-14 & Yenikapı-2 & 0.741 & $\mathrm{C}$ & $\mathrm{EF}_{\mathrm{Cu}}=2.50$ & $\mathrm{LE}$ & $\mathrm{C}_{\mathrm{f}} \mathrm{Cu}=0.73$ & $\mathrm{LC}$ & 0.48 & $\mathrm{NC}$ \\
\hline C-15 & Kumkapı-1 & 0.954 & $\mathrm{CD}$ & $\mathrm{EF}_{\mathrm{Cu}}=6.00$ & $\mathrm{HE}$ & $\mathrm{C}_{\mathrm{f}} \mathrm{Cu}=\underline{1.90}$ & MC & 0.67 & $\mathrm{NC}$ \\
\hline C-16 & Kumkapı-2 & 1.270 & HP & $\mathbf{E F}_{\mathrm{Cu}}=7.50$ & HE & $\mathrm{C}_{\mathrm{f}} \mathrm{Cu}=\underline{\mathbf{2 . 8 0}}$ & MC & 0.84 & $\mathrm{NC}$ \\
\hline $\mathrm{C}-17$ & Boğaziçi & 0.613 & $\mathrm{C}$ & $\mathrm{EF}_{\mathrm{Cu}}=4.10$ & $\mathrm{VE}$ & $\mathrm{C}_{\mathrm{f}} \mathrm{Cu}=\underline{1.20}$ & $\mathrm{MC}$ & 0.41 & $\mathrm{NC}$ \\
\hline C-18 & Haydarpaşa & $\underline{1.152}$ & HP & $\mathrm{EF}_{\mathrm{Cu}}=2.00$ & $\mathrm{LE}$ & $\mathrm{C}_{\mathrm{f}} \mathrm{Cu}=0.58$ & $\mathrm{LC}$ & 0.36 & $\mathrm{NC}$ \\
\hline C-19 & Üsküdar & 0.791 & $\mathrm{C}$ & $\mathrm{EF}_{\mathrm{Cu}}=2.90$ & $\mathrm{LE}$ & $\mathrm{C}_{\mathrm{f}} \mathrm{Cu}=\underline{1.30}$ & MC & 0.60 & $\mathrm{NC}$ \\
\hline $\mathrm{C}-20$ & Kadıköy & 0.718 & $\mathrm{C}$ & $\mathrm{EF}_{\mathrm{Cu}}=3.10$ & $\mathrm{VE}$ & $\mathrm{C}_{\mathrm{f}} \mathrm{Cu}=\underline{1.20}$ & MC & 0.53 & $\mathrm{NC}$ \\
\hline $\mathrm{C}-21$ & Kınalı Island & 0.326 & $\mathrm{HC}$ & & & & & 0.29 & $\mathrm{NC}$ \\
\hline $\mathrm{C}-25$ & M. Ereğlisi & 0.729 & $\mathrm{C}$ & & & & & 0.53 & $\mathrm{NC}$ \\
\hline
\end{tabular}

LE: little enrichment; VE: very enrichment, HE: highly enrichment (definitely not of shell origin); LC: little contamination, MC: middle contamination; PLI value $>1$ indicates the presence of contamination (C), PLI < 1 indicates no contamination (NC); PI: 0-0.50 (max. clean (MC)), 0.50-0.85 (clean (C)), 0.50-0.85 (max. clean (MC)), PI: 0.85-1.00 clean-dirty transition (CD), PI: 1.00-1.15 polluted (P), PI $>1.15$ (high polluted zone (HP) 
A rich foraminifera group was observed and a total of 15 genera and 30 species were identified. Color changes were observed in Ammonia compacta. The changes in the foraminifer shells were assessed by examining the concentrations of toxic elements at the levels where morphological changes occurred in the foraminifer shells. The colour changes seen in the dirty zones were more common, especially in Ammonia compacta. Foraminifer shells were found to have different shades, ranging from yellowish brown to black. In order to determine the causes of these discolorations, shells were subjected to surface element analysis in an SEM. In places where the $S$ values were high, dark grey-black colors were dominant. At places where the Fe and Mn values were high, the yellow-yellowish brown color was dominant. In areas where heavy metal concentrations are high, PI values are higher than critical values $(\mathrm{PI}=1)$ and are defined as dirty areas. The number of genera, species and individuals of foraminifera is quite low in the places where pollution is high. It is thought that the low number of foraminifera samples in samples taken from Küçükçekmece, Büyükçekmece, Ambarlı and Avcılar regions are due to ship traffic and discharge of domestic and industrial wastewater into the sea.

This study, scientifically compared with the studies conducted in the West Marmara Sea (Yümün, 2017) and in the Gemlik region (Meriç et al., 2009; Yümün et al., 2021). In all three studies, it is seen that the pollution increases at the ship roads, ports and at the points where the streams carrying industrial wastes flow into the sea. However, heavy metal pollution caused by agricultural activities and geological formations creates differences according to the agricultural and geological structure of each region.

In future studies, a comparison should be made with the data of this study and previous studies. In this way, time-dependent pollution changes on the sea floor will be followed over time. In addition to these, an evaluation should be made by taking samples from the rivers pouring into the sea from the land.

Acknowledgements. The author thanks FORMKAR Ltd. Şti for their studies on drilling and core sampling and Melike ÖNCE for the preparation of the samples in the laboratory and also for the separation studies of other fossils. The author also thanks Y1ldı Technical University Scientific Research Projects Commission for accepting and financing this study (Project no: FBA-2018-3351).

\section{REFERENCES}

[1] Adamo, P., Arienzo, M., Imperato, M., Naimo, D., Nardi, D., Stanzione, D., (2005): Distribution and partition of heavy metals in surface and sub-surface sediments of Naples City Port. - Chemosphere 61(6): 800-809.

[2] Aksu, A. E., Yaşar, D., Uslu, O. (1997): Assessment of Marine Pollution in Izmir Bay: Heavy Metal and Organic Compound Concentrations in Surficial Sediments. - Turkish Journal of Engineering and Environmental Sciences 22(5): 387-415.

[3] Algan, O., Balkıs, N., Çağatay, M. N., Sarı, E. (2004): The sources of metal in the shelf sediments of the Marmara Sea, Turkey. - Environmental Geology 46: 932-950.

[4] Bakan, G., Kaya, S., Özkoç, H. B., Kurt, P. (1999): Certain organic pollutant levels in surface sediment of the Mid Black Sea Coast of Turkey. - Medcoast 99: 455-464.

[5] Balkıs, N., Topçuoğlu, S., Güven, K. C., Öztürk, B. (2007): Heavy metals in shallow sediments from the Black Sea, Marmara Sea and Aegean Sea regions of Turkey. Journal of Black Sea/Mediterranean Environment 13(2).

[6] Bampton, M. (1999): Anthropogenic Transformation. - In: Environmental Geology. Encyclopedia of Earth Science. Springer, Dordrecht. https://doi.org/10.1007/1-40204494-1_17. 
[7] Baştürk, O., Yılmaz, A., Saydam, A. C., Salihoğlu, I. (1988): Oceanography of the Turkish Straits-Second Annual Report, Vol. II, Health of the Turkish Straits: Chemical and Environmental Septs of the Sea of Marmara. - Institute of Marine Sciences, Erdemli/Mersin.

[8] Buat - Menard, P., Chesselet, R. (1979): Variable in fluence of the atmospheric flux on the trace metal chemistry of oceanic suspended matter. - Earth Planet Science Lett 42: 399-411.

[9] Daskalakis, K., D., O'Connor, T. P. (1995): Normalization and elemental sediment contamination in the coastal United States. - Environmental Science and Technology 29: 470-477.

[10] Feng, H., Han, X., Zhang, W., Yu, L. (2004): A preliminary study of heavy metal contamination in Yantze River in Tertidal Zone due to urbanization. - Marine Pollution Bulletin 49: 910-915.

[11] Galuszka, A., Migaszewski, Z. M., Zalasiewicz, J. (2014): Assessing the Anthropocene with geochemical methods. - Geological Society, London, Special Publications 395: 221238.

[12] Hakanson, L. (1980): An ecological risk index for aquatic pollution control. A sedimentological approach. - Water Research 14975-1001.

[13] Halstead, M. J., Cunninghame, R. G., Hunter, K. A. (2000): Wet deposition of trace metals to a remote site in Fiordland, New Zealand. - Atmospheric Environment 34: 665676.

[14] Kam, E. and Önce, M. (2016): Pollution potential of heavy metals in the current sea sediments between Bandırma (Balıkesir) and Lapseki (Çanakkale) in the Marmara Sea. Journal of Engineering Technology and Applied Sciences 1(3): 141-148.

[15] Karaca, A. (1997): Heavy Metal Pollution Caused by Motor Vehicle Emissions in Erzurum Soils. - Ataturk Univ. Institute of Science, Department of Environmental Sciences, Master's Thesis, Erzurum (in Turkish).

[16] Knezovich, J. P., Harrison, F. L. (1987): The bioavailability of sediment - sorbed organic chemicals. A review. - Water Air and Soil Pollution 32: 233-245.

[17] Krauskopf, K. B. (1985): Introduction to Geochemistry. 2nd Ed. - McGraw-Hill International, New York.

[18] Krige, D. G. (1951): A statistical approach to some basic mine valuation problems on the Witwatersrand. - Journal of the Chemical, Metallurgical and Mining Society of South Africa 52: 119-139.

[19] Küçük, Y. K. ve Topçu, A. (2012): Pollution caused by sea transportation. - Ankara University Journal of Environmental Sciences 4(2): 75-79 (in Turkish).

[20] Kutluk, E. (2018): Environmental effects of traffic load caused by ships passing through the Bosporus: a study on Ro-Ro Ships. - Marmara University Journal of Political Science 6(1): 285-310 (in Turkish).

[21] Long, E. R., MacDonald, D. D., Smith, S. L., Calder, F. D. (1995): Incidence of adverse biological effects within ranges of chemical concentrations in marine and estuarine sediments. - Environmental Management 19: 81-97.

[22] Mason, B., Moore, C. B. (1982): Principles of Geochemistry. - Wiley \& Sons, New York.

[23] Meriç, E., Avşar, N., Nazik, A., Yokeş, B., Barut, I. F., Eryılmaz, M., Kam, E., Taşkın, H., Başsarı, A., Dinçer, F., Bircan, C., Kaygun, A. (2012): Ilıca Bay (Çeşme - Izmir) benthic foraminifera, ostracod communities and migrant foraminifera and abnormal individuals originating from the Pacific Ocean and the Red Sea. - Journal of Mineral Exploration and Exploration 145: 62-78.

[24] Meriç, E., Avşar, N., Nazik, A., Yokeş, B., Ergin, M., Eryılmaz, M., Yücesoy-Eryılmaz, F., Gökaşan, E., Suner, F., Tur, H., Aydın, Ş., Dinçer, F. (2009): Geochemistry of current benthic foraminifera, ostracoda, mollusc society and sediment distribution of Çanakkale Strait. - Turkey Geology Bulletin 52(2). 
[25] Morillo, J., Usero, J., Gracia, I. (2002): Heavy metal fractionation in sediments from the Tinto River (Spain). - International Journal of Environmental \& Analytical Chemistry 82: 245-257.

[26] Morillo, J., Usero, J., Gracia, I. (2002): Partitioning of metals in sediments from the Odiel River (Spain). - Environmental International 28(4): 263-271.

[27] Niencheski, L. F., Windom, H. L., Smith, R. (1994): Distribution of particulate trace metal in Patos Lagoon Estuary, Brazil. - Marine Pollution Bulletin 28: 96-102.

[28] Özdemir, Ü. (2012): Examination of welded marine pollution from ships in Turkey. Batman University, Journal of Life Sciences 1(2): 373-384 (in Turkish).

[29] Pekey, H., Karakaş, D., Ayberk, S., Tolun, L., Bakoğlu, M. (2004): Ecological risk assesment using trace elements from surface sediments of Izmit Gulf (Northeastern Marmara Sea) Turkey. - Marine Pollution Bulletin 48: 946 - 953.

[30] Rodríguez-Barroso, M. R., Benhamou, Y., El Moumni, B., El Hatimi, I., Garica-Morales, J. L. (2009): Evaluation of metal contamination from North of Morrocco: geochemical and statistical approaches. - EnvironMonitAsses 159:169-181.

[31] Şahin, A. (2014): Land Use, Change and Forests in the Province of Istanbul since 1970: Problems of Istanbul Forests and Solution Offers. - Foresters' Association of Turkey Marmara Branch Publication 3: 51-87 (in Turkish).

[32] Sarı, E. (2004): Marmara Denizi Doğusunda Çökel Jeokimyası ve Sedimantolojisi Yöntemleri ile Fay Etkinliğinin Araştırılması. - Doktora Tezi, İstanbul Üniversitesi Deniz Bilimleri ve İşletmeciliği Enstitüsü, İstanbul.

[33] Sarı, E., Çağatay, M. N. (2001): Distributions of heavy metals in the surface sediments of the Gulf of Saros, NE Aegean Sea. - Environment International 26: 169-173.

[34] Taylor, S. R., McLennan, S. M. (1995): The geochemical evolution of the continental crust. - Reviews of Geophysics 33: 241-265.

[35] Tomlinson, D. L., Wilson, J. G., Harris, C. R., Jeffney, D. W. (1980): Problems in the assessment of heavy metal levels in estuaries and the formation of a pollution index. Helgol. Wiss. Meeresunters 33: 566-572.

[36] Turekian, K. K., Wedepohl, K. H. (1961): Distribution of the elements in some major units of the earth's crust. - Geology Society America Bulletin 72: 175-192.

[37] Ulaştırma Bakanlığı - UB. (2011): Turkey Transportation and Communication Strategy: Target 2023. - T. C. Ministry of Transport, Ankara (in Turkish).

[38] Valdes, J., Vargas, G., Sifeddine, A., Ortlieb, L., Guinez, M. (2005): Distribution and enrichment evaluation of heavy metals in Mejillones Bay $\left(23^{\circ} \mathrm{S}\right)$, Northern Chile: geochemical and statistical approach. - Marine Pollution Bulletin 50(12): 1558-1568.

[39] Yümün, Z. Ü. (2016): The effects of heavy metal concentrations in the Çanakkale Strait (Turkey): morphological differences in the Holocene foraminiferal assemblages. Journal of Engineering Technology and Applied Sciences 1(2): 77-88.

[40] Yümün, Z. Ü. (2017): The effect of heavy metal pollution on foraminifera in the western Marmara Sea (Turkey). - Journal of African Earth Science 129: 346-365.

[41] Yümün, Z. U., Kam, E. (2019): Ecological analysis of heavy metal and radioactivity potential of Holocene sediments in Iznik Lake. - Nükleonika 64(3): 103-109.

[42] Yümün, Z. U., Önce, M. (2017): Monitoring heavy metal pollution in foraminifera from the Gulf of Edremit (Northeastern Aegean Sea) Between Izmir, Balıkesir and Çanakkale (Turkey). - Journal of African Earth Sciences 130: 110-124.

[43] Yümün, Z. U., Kam, E., Önce, M. (2019): Analysis of toxic element with Icp-Oes and libs methods in marine sediments around the Sea of Marmara in Kapıdağ Peninsula. Journal of Engineering Technology and Applied Sciences: 4(1): 43-50.

[44] Yümün, Z. Ü., Kam, E., Dinçer, A., Önce, M., Yümün, S. (2021): The investigation of toxic element pollution and radioactivity analyses of marine sediments in the Gulf of Gemlik (Bursa, Turkey). - Applied Ecology and Environmental Research 19(2): 881-900. 